\title{
Racial capitalism, climate justice, and climate displacement
}

OÑATi SOCiO-Legal Series, Volume 11 ISSUe 1 (2021), 108-147: Climate Justice IN THE ANTHROPOCENE

DOI LINK: HTTPS://DOI.ORG/10.35295/OSLS.IISL/0000-0000-0000-1137

RECEIVED 20 JANUARY 2020, ACCEPTED 06 APRIL 2020

\section{CARMEN G. GONZALEZ* (D)}

\section{Abstract}

This article expands our understanding of climate justice by demonstrating how racial subordination, environmental degradation, and the fossil fuel-based capitalist world economy are interrelated. It uses these insights to critique the emerging legal and policy responses to climate change-induced displacement and to examine alternative approaches emerging from climate-vulnerable states and peoples. The article argues that racialized communities all over the world have borne the brunt of carbon capitalism from cradle (extraction of fossil fuels) to grave (climate change) and that a race-conscious analysis of climate change and climate displacement can reveal the commonalities among seemingly distinct forms of oppression in order to forge the alliances necessary to achieve just and emancipatory outcomes.

\section{Key words} capitalism

Climate change; climate justice; climate refugees; climate displacement; racial

\section{Resumen}

Este artículo amplía nuestra comprensión de la justicia climática al demostrar cómo la subordinación racial, la degradación medioambiental y la economía mundial capitalista basada en los combustibles fósiles están relacionados entre sí. Se parte de estos enfoques para criticar las respuestas emergentes de tipo jurídico y político al desplazamiento provocado por el cambio climático y para analizar abordajes alternativos provenientes de estados y pueblos vulnerables por el clima. El artículo argumenta que las sociedades racializadas de todo el mundo son las mayores damnificadas por el capitalismo basado en el carbón, desde la cuna (extracción de combustibles fósiles) hasta la tumba (cambio climático) y que un análisis del cambio climático y del desplazamiento subsiguiente que tenga en cuenta la raza revela las

\footnotetext{
* Morris I. Leibman Professor of Law, Loyola University Chicago School of Law, 25 E Pearson St, Chicago, IL 60611, USA, Professor Emerita, Seattle University School of Law. Email address: cgonzalez19@luc.edu
} 
características comunes de formas aparentemente distintas de opresión, de cara a forjar las alianzas necesarias para conseguir resultados justos y emancipatorios.

Palabras clave

Cambio climático; justicia climática; refugiados climáticos; desplazamiento climático; capitalismo racial 


\section{Table of contents}

1. Introduction 111

2. Climate Justice, Racial Capitalism, and Coloniality: Framing the Issues 112

2.1. The Concept of Climate Justice 112

2.2. Racial Capitalism and the Anthropocene. 113

2.3. Racial Capitalism and Climate Change 117

3. Climate Justice and Climate Displacement: Evaluating the Emerging Approaches

3.1. Climate Justice and the Paris Agreement....................................................120

3.2. Legal and Policy Approaches to Climate Displacement......................................121

4. A Just Approach to Climate Displacement?..............................................................128

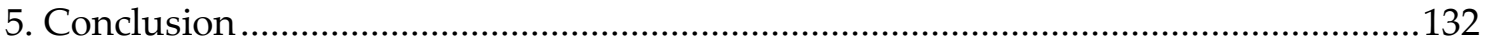

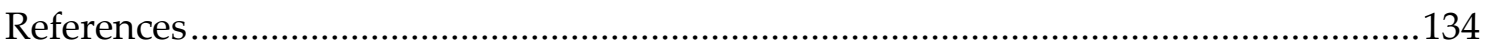




\section{Introduction}

The spectre of dark-skinned migrants threatening national borders and bringing crime, disorder, and disease haunts public debates over climate change in Europe and the United States (Telford 2018). Climate change is predicted to displace between 25 million and 1 billion people by 2050 (Kamal 2017, n.p.). The widely differing projections reflect the complex social, economic, and environmental causes of migration that make it "extremely difficult to isolate climate change and environmental factors as the sole drivers behind the decision to move" (International Organization for Migration - IOM 2014, p. 6). Despite the consensus among scholars that migration is a multi-faceted phenomenon that cannot be ascribed exclusively to environmental factors, alarmist narratives over climate change-induced migration have sparked xenophobic, militarized responses, including proposals to construct or expand border walls (Miller 2017, Klepp 2017).

The Paris Agreement, adopted in December 2015 under the auspices of the United Nations Framework Convention on Climate Change (UNFCCC), breaks new ground by recognizing the duty of states to respect human rights, including the rights of migrants, when taking action to combat climate change (Paris Agreement 2015, preamble). The agreement incorporates loss and damage into the climate regime (art. 8), and the Paris Decision adopting the agreement expressly addresses climate change-related displacement through the Warsaw International Mechanism for Loss and Damage (UNFCCC 2016, para. 49). Regrettably, these important advances have been overshadowed by the global North's aggressive measures to repel, detain, and deport rising numbers of migrants and refugees fleeing war, poverty and persecution. The Trump administration has portrayed Central American families seeking asylum in the United States as "social parasites and criminals" (Chen 2018, n.p.) and has threatened to close the U.S.-Mexican border (Collinson 2019). In Europe, migrants from Africa and the Middle East are often depicted as violent, patriarchal and prone to radicalization and terrorism (Gutiérrez Rodríguez 2018, Telford 2018), and governments have adopted increasingly restrictive measures to deter migration (Boghani 2018).

The cruel and inhumane response of the European Union (EU), the United States (US), and Australia to refugees and migrants does not bode well for efforts to address climateinduced displacement. By intercepting migrant ships and shutting down the major routes used by smugglers, European countries have increased the refugee death toll "as smuggling networks employ more dangerous routes and methods using smaller, overcrowded vessels that are not seaworthy" (Birnbaum 2017, n.p.). Australia's indefinite detention of migrants and refugees in remote offshore processing centers located in Nauru and on Manus Island in Papua New Guinea has provoked "violent deaths, horrific acts of self-harm and abuse, and mass protests" among the desperate detainees, leading Amnesty International to denounce the conditions in these processing centers as "a human rights catastrophe" (Davidson 2016, n.p.). The US government's practice of criminally prosecuting migrants, removing children from their families and confining thousands of migrant children in kennel-like, ice-cold cells has generated widespread national and international condemnation (Cummings-Bruce 2018, Chalabi 2018, Delgado 2019, Nawyn 2019). 
Despite increasingly polarized and racialized debates over migration, the legal scholarship on climate displacement has, for the most part, maintained a strong doctrinal focus that avoids the racial dimensions of climate justice. This article draws upon the interdisciplinary literature on racial capitalism and coloniality to deepen our collective understanding of climate justice in the Anthropocene. It applies these insights to the emerging legal responses to the plight of climate-displaced persons. For the purposes of this article, climate-displaced persons (CDPs) are those who are displaced (temporarily or permanently) within their own country of residence or cross national borders due to immediate or slow-onset climate change-related calamities such as sea level rise, drought and desertification. While this definition includes internally displaced persons as well as those who migrate to countries in the South and the North, this article focuses on the obligations of the global North toward CDPs given its disproportionate contribution to climate change and its consequent legal and moral duty to address the problem.

The remainder of this article proceeds as follows: Section 2 traces the origins of the concept of climate justice, discusses its relationship to the Anthropocene and expands this concept by engaging with the literature on racial capitalism and coloniality. Section 3 examines the ways in which climate justice and climate displacement are addressed in the UNFCCC and the Paris Agreement, and analyzes emerging legal and policy approaches to climate displacement. Section 4 uses the insights of racial capitalism and coloniality to discuss alternative approaches to climate displacement proposed by climate-vulnerable states and communities. Section 5 concludes that analyzing the climate crisis through a racial capitalist lens can forge alliances among the many social groups harmed by fossil fuel-based capitalism. Instead of demonizing CDPs, a decolonial perspective based on the recognition of common vulnerability to the economic and ecological dislocations of carbon capitalism can open the door to emancipatory approaches to displacement grounded in climate justice.

\section{Climate Justice, Racial Capitalism, and Coloniality: Framing the Issues}

This section defines climate justice and examines the ways that race-conscious perspectives grounded in the coloniality of power can enhance our understanding of this concept.

\subsection{The Concept of Climate Justice}

The concept of climate justice has its origins in the theory and practice of the environmental justice movement. During the last four decades, environmental justice has become a rallying cry of communities engaged in thousands of ecological struggles in the global North and South (Temper et al. 2015). Environmental justice scholars and activists have developed a four-part definition that illustrates the distinct, but interrelated aspects of this concept: distributive injustice in the form of disproportionate exposure to environmental hazards such as extractive and polluting industries; procedural unfairness due to the denial of meaningful opportunities to participate in governmental decision-making; corrective injustice arising from inadequate legal redress for environmental harm; and social injustice, because environmental degradation is inextricably linked with broader social ills, such as racism and poverty (Kuehn 2000, Gonzalez 2013). 
Inspired by the rise of environmental justice movements, a coalition of environmental justice, religious, policy, and advocacy groups mobilized around the concept of climate justice during successive Conferences of the Parties (COPs) to the UNFCCC (Schlosberg and Collins 2014). In 2002, these groups published the Bali Principles of Climate Justice - one of the earliest articulations of the idea of climate justice by a transnational social movement (Bali Principles 2002). The Bali Principles reject the growth-based model of economic development that has produced the climate crisis; condemn the inequitable impact of fossil fuel production on vulnerable communities; seek procedural and participatory justice; and demand corrective justice through the transfer of resources from those with historic responsibility for climate change to those most susceptible to its consequences (Bali Principles 2002, Schlosberg and Collins 2014).

This article adopts a four-part definition of climate injustice. Climate change is a paradigmatic example of distributive injustice because the global North is responsible for the vast majority of historic greenhouse gas emissions and has reaped the corresponding economic benefits, while those who are disproportionately harmed by climate change are the states and peoples who have contributed least to the problem (Anand 2004, Mickelson 2005). Climate change raises issues of procedural injustice because the North dominates the institutions of global economic and environmental governance and frequently ignores Southern perspectives and priorities (Anand 2004, Hossay 2006, Peet 2009). Climate change is a manifestation of corrective injustice, because those who bear the greatest climate change-induced harms (including indigenous peoples and small island states) have been unable to obtain compensation or redress for their injuries (Tsosie 2007, Burkett 2009). Finally, climate change is inextricably linked to broader social injustice, including an economic order that systematically exacerbates poverty and inequality while exceeding the limits of the planet's finite ecosystems (Roberts and Parks 2008, Gonzalez 2013).

Climate justice, like environmental justice more broadly, is grounded in human rights, including the rights to life, health and cultural integrity; the right to a healthy environment; the right to be free from race and sex discrimination; and the right to information, participation, and access to justice (Gonzalez 2013). In January 2009, the United Nations High Commissioner for Human Rights (UNHCHR) issued a report on the threats posed by climate change to a variety of human rights, including the rights to life, food, water, health, housing and self-determination, and pointed out that climate change will have a disproportionate impact on those who are already vulnerable due to age, gender, poverty, disability and minority status (UNHCHR 2009). In 2019, the United Nations Special Rapporteur on Extreme Poverty and Human Rights used the term "climate apartheid" to describe the divide between the affluent (who possess the resources to protect themselves from climate-related heat waves, food shortages, and conflict) and the rest of humankind (who will be left to suffer) (UNHRC 2019, p. 14, para. 50). In the past decade, human rights treaty bodies have provided detailed recommendations to states on ways to ensure that climate change policies comply with legally binding human rights obligations (CIEL and GIESCR 2018, 2019).

\subsection{Racial Capitalism and the Anthropocene}

An analysis of climate change would be incomplete without situating the anthropogenic breach of planetary boundaries in the larger context of the Anthropocene. The concept 
of the Anthropocene was introduced by Paul Crutzen and Eugene Stoermer (2000) to describe the unprecedented human dominance and disruption of Earth system processes essential to the flourishing of human and non-human life. The authors attributed the emergence of the Anthropocene to the destructive technologies developed by humanity and sought "to guide [hu]mankind towards, global, sustainable, environmental management" (Crutzen and Stoermer 2000, p. 18.).

This undifferentiated view of humanity has been widely criticized for obscuring the underlying social and economic drivers of anthropogenic Earth system disruption, including colonial conquest, imperial dispossession and the imposition of a global capitalist order that systematically abuses nature and exploits large segments of the world's population (Moore 2015, Haraway 2016, Baskin 2019). Some scholars propose the notion of the Capitalocene to better address the role of capitalism as the underlying cause of contemporary social and ecological crises (Moore 2016). Others have emphasized the role of racism and colonial violence as the means through which humans and nature are objectified and exploited (Yusoff 2018).

Political theorist Cedric Robinson (2000) and sociologist Aníbal Quijano (2000, 2007, 2014) argue that racism and capitalism are inextricably intertwined. The extraction of wealth from nature was operationalized through slavery, the conquest and dispossession of indigenous peoples, and the colonial and postcolonial domination by white Euro-American elites of large segments of the world's population. Robinson (2000) uses the term "racial capitalism" to denote this symbiotic relationship between racism and capitalism. He argues that capitalism emerged from a feudal order thoroughly infused with racial hierarchies, and then evolved into a world system that transforms regional and cultural differences into racial forms of domination, including slavery, imperialism and genocide.

Quijano introduces the term "coloniality of power" to refer to the Eurocentric racial and cultural hierarchies and institutional forms of domination (such as the nation-state) imposed through colonialism that structure the contemporary capitalist world system including the North-South divide. These hierarchies persist long after the departure of the colonial administration, and continue to structure economic and social relations (Quijano 2000, 2007). Scholars in a variety of disciplines have extended Quijano's definition of the coloniality of power to encompass the interlocking systems of oppression that constitute the capitalist world system, including those that privilege core (North) over periphery (South), men over women, Christians over non-Christians, Europeans over non-Europeans, heterosexuals over homosexuals, and Western knowledge over non-Western knowledge (Grosfoguel 2006). What distinguishes this decolonial perspective from Robinson's approach is that it emphasizes race and racism as a cross-cutting principle of the capitalist world system while also recognizing other intersecting forms of subordination (Grosfoguel 2016). For example, racial hierarchies shape the national and international division of labour, consigning those constructed as non-white to the most dirty and dangerous forms of employment (Fraser 2016, Bhattacharyya 2018, Faber 2018). Similarly, gender hierarchies relegate women to unpaid domestic labour including cooking, cleaning, and raising children that reproduces the workforce (Bhattacharyya 2018). Hyper-exploited racialized women generally perform the waged domestic and care work that enables more privileged 
women to enter elite labour markets in addition to performing unpaid domestic labour in their own homes (Battacharya 2018). In other words, race and gender hierarchies intersect, conferring greater status on some white women than many non-white men, and generally placing non-white women in a subordinate position in relation to both groups (Crenshaw 1989, Grosfoguel 2006).

While informed by the insights of critical race theory, including scholars of intersectionality, this article adopts a structural approach to race and racism grounded in political economy. Building on the work of Quijano and Robinson, the article examines the ways that capitalism deploys race and racism as techniques of exclusion and control, creating expendable geographic locations (sacrifice zones) and expendable people. As planetary boundaries continue to be breached (Steffen et al. 2015), racialized populations, including those displaced by climate change, will be exposed to increasing levels of violence and exclusion. Racism is thus not simply a form of bias or discrimination, but an integral part of a world system that subjects growing segments of the world's population to precarity and premature death.

The term "racism" is used in this article to refer to the degradation and objectification of human beings based on a variety of indicators, most commonly physical characteristics (such as skin colour), but also ethnicity, indigeneity, culture, caste, language, religion, geographic location, and geographic origin (Grosfoguel 2016). Racialization is the process through which specific bodies are classified as superior or inferior based on the distinct set of markers adopted in a region or nation at a particular time (Grosfoguel et al. 2014). Which groups are racialized and the narrative that accompanies that racialization varies substantially across place and time in relation to changing economic and political conditions (Reed 2013). For example, some groups that are currently recognized as white (such as Jews and the Irish) have a long history of being classified as non-white (Ignatiev 1995, Brodkin 1998).

Racial hierarchies serve distinct economic objectives and maintain population-specific modes of control. In the US, for example, the founding logic of anti-Black racism was labour exploitation (Saito 2014, Wolfe 2016). When slavery was abolished, other mechanisms of exploitation and control became dominant, including share-cropping, debt peonage, convict-leasing, lynching, and segregation (Sassen 2014, Wolfe 2016). By contrast, the logic of anti-Native racism was the elimination of the Native in order to appropriate indigenous lands (Saito 2014). Consequently, settler-colonial states like the US, Australia and Canada sought to dissolve Native societies and extirpate Native land claims through genocide and various forms of ethnocide, including "the breaking-down of Native title into alienable individual freeholds, Native citizenship, child abduction, religious conversion, resocialisation in total institutions such as missions or boarding schools, and a whole range of bio-cultural assimilations" (Wolfe 2016, p. 33).

Eurocentric racial and cultural hierarchies correspond, at least in part, to Boaventura de Sousa Santos' notion of the "abyssal line" demarcating those deemed fully human from those deemed less than human (Santos 2014). Conflicts involving those on one side of the abyssal line are managed through discourses of liberty, equality and autonomy. Those on the other side of the abyssal line are treated as non-humans/sub-humans and occupy a zone of violence and dispossession (Grosfoguel 2016). As Sundberg (2008, p. 
570) observes, "[r]acial thinking provides a powerful rationale for why inequalities and injustices between groups of people are socially and legally acceptable".

This article focuses on the subordination of those below the abyssal line while recognizing that abyssal and non-abyssal exclusions coexist and that some groups cross between these two forms of exclusion in their daily lives. Santos (2018) provides examples that illustrate the distinction between abyssal and non-abyssal exclusion.

First example: In a predominantly white society, a young Black man in secondary school (...) may well consider himself excluded, whether because he is often avoided by his schoolmates or because the syllabus deals with materials that are insulting to the culture or history of peoples of African descent. Nonetheless, such exclusions are not abyssal; he is part of the same student community and, at least in theory, has access to mechanisms that will enable him to argue against discrimination. On the other hand, when the same young man on his way back home is stopped by the police, evidently due to ethnic profiling and is violently beaten, at such a moment, the young man crosses the abyssal line. (Santos 2018, p. 22)

The abyssal line operates on a global scale between centres and peripheries - the North and South. It also operates within nations. In the global North, indigenous peoples, racial and ethnic minorities and immigrants from the global South are disproportionately classified as subhuman or non-human. In the global South, Westernized elites frequently engage in internal colonialism, reproducing racist practices against particular social groups (Grosfoguel et al. 2014, Gonzalez 2015). The abyssal line is perhaps most evident in the zones of extreme violence and degradation, such as Guantánamo, Darfur, Iraq, Palestine, and Yemen. It is also evident in the prisons and migrant detention camps of the global North (Santos 2014). The distinction between abyssal and non-abyssal exclusion is not grounded in the intensity of the pain and deprivation experienced by individual or collective bodies, but "refers to the indifference with which suffering is inflicted, indifference meaning both cold-bloodedness and impunity" (Santos 2018, p. 95).

The regulation of migration is "among the most consistently racialized practices of most contemporary states" (Bhattacharyya 2018, p. 129). European nations and settler-colonial states historically encouraged European mobility while restricting the movement of persons classified as non-white. Between 1800 and 1925, for example, approximately 48 million Europeans migrated to New Zealand, Australia, Argentina, South Africa, and the United States as a consequence of migration policies designed to "whiten" these states and territories (Massey 2000). During the same period, the newly sovereign states in the Americas adopted a series of laws and policies to reduce the migration of racialized populations, including head taxes, outright prohibitions (such as the infamous 1882 Chinese Exclusion Act in the United States), and racially coded naturalization and immigration policies (Gutiérrez Rodríguez 2018). Australia adopted a "White Australia Policy" in 1904, and banned migration from Africa, Southeast Asia, and South Asia (Gutiérrez Rodríguez 2018).

In the decades following World War II, the demographic composition of Europe and the US changed due to migratory flows from the global South, challenging Euro-American white national identity (Gutiérrez Rodríguez 2018). Until the 1960s, the US imposed racially discriminatory national origin quotas on new migrants that favored Northern 
Europeans (Tichenor 2002). When these quotas were lifted, migration from Asia, Africa, and Latin America increased significantly - triggered by war, poverty, and neoliberal economic reforms (Gonzalez 2011). European States also grew more racially and ethnically diverse due to the influx of racialized citizens from the former colonies and migrant laborers recruited from Turkey, Morocco and elsewhere (Telford 2018, Gutiérrez Rodríguez 2018).

Notwithstanding these demographic changes, the current "refugee crisis" has revealed the profound racial animus against persons classified as non-white. In Europe, the US and other settler-colonial nations, the population is generally divided "between those whose movement is a manifestation of liberty, and should therefore be maximized, and those whose freedom is a problem, and should therefore be tightly regulated" (Kotef 2015, p. 100). While corporations freely roam the world, racialized bodies are policed, detained, incarcerated, and deported (Sheller 2018). This racialized abyssal line has profound implications for climate-induced migration. The following section draws upon these insights to expand our understanding of climate justice.

\subsection{Racial Capitalism and Climate Change}

An analysis of climate change through the lens of racial capitalism and coloniality reveals additional aspects of climate injustice that are obscured by the four-part definition articulated in this article (distributive, procedural, corrective, and social). In order to appreciate the full extent of climate injustice, it is important to examine the ways that race is inscribed in the history of carbon capitalism and the sacrifice zones of both the fossil fuel economy and the emerging green energy economy.

First, the colonization of the Americas and the transatlantic slave trade established the material and ideological foundations of capitalism - a system based on extraction, accumulation through dispossession, and white supremacy (Davis and Todd 2017, Yusoff 2018).

The Anthropocene is the epoch under which 'humanity' - but more accurately, petrochemical companies and those invested in and profiting from petrocapitalism and colonialism - have had such a large impact on the planet that radionuclides, coal, plutonium, plastic, concrete, genocide and other markers are now visible in the geologic strata. (Davis and Todd 2017, p. 765; emphasis added)

The genocide of the indigenous populations of the Americas in the 1500s was so massive (nearly 50 million deaths) that farming collapsed and forests rebounded. The forests removed such large amounts of carbon from the atmosphere as to cause a significant dip in atmospheric carbon dioxide levels in the 1600s, measurable in Antarctic ice cores leading Lewis and Maslin (2015, pp. 175-177) to propose 1610 as the beginning of the Anthropocene. This early marker of the Anthropocene coincided with the importation of slave labour to extract gold, silver and copper and later the sugar and cotton that fueled the Industrial Revolution (Yusoff 2018, pp. 29-33).

Starting the Anthropocene at 1610 captures all impacts of the Industrial Revolution, which many scientists and historians consider a key part of the Anthropocene-because European annexing of the Americas was an essential factor in providing food energy and raw material imports that were critical elements allowing an Industrial Revolution to take place. (Lewis and Maslin 2018, p. 319) 
Colonization and slavery were therefore central rather than peripheral to the Industrial Revolution and the birth of carbon capitalism (Williams 1994, Beckert 2014, Blackburn 1997, Yusoff 2018).

Second, the "slow violence" inflicted by the fossil fuel industry on racialized and poor communities throughout the world remains a central feature of contemporary capitalism (Nixon 2013, Soyapi and Kotzé 2016). The extraction, processing, transportation, refining and combustion of fossil fuels has placed disproportionate environmental burdens on racialized communities in the global North and South. From the Niger Delta to the Canadian tar sands and the countless communities living in the shadow of polluting petrochemical facilities and power plants, the life cycle impacts of fossil fuels include eviction from ancestral lands; desecration of sacred sites; poisoning of air, land, and water; fires, explosions, and industrial accidents; loss of subsistence fishing and hunting rights; and exposure to significant health hazards (Klein 2014). Local and transnational environmental justice struggles against coal mining, petroleum drilling, fracking, oil and gas pipelines, and polluting refineries and power plants are thus inextricably intertwined with the struggle for climate justice.

Third, fossil fuels are concentrated in particular countries and regions such as the Middle East that have been targeted over and over for invasion, occupation, and exploitation. The North's bloody resource wars, its collusion with despotic petro-states, and the resulting death, destruction and displacement of racialized Muslim and Arab populations are amongst the most violent ongoing manifestations of climate injustice (Klare 2004, Natarajan 2012, Klein 2016). When persons displaced by these conflicts seek refuge in the global North, they are branded as potential terrorists and subjected to restrictive border controls, including the notorious "Muslim ban" on travel to the US from certain predominantly Muslim countries (Liptak and Shear 2018, Telford 2018).

Fourth, those most susceptible to climate-related disasters and slow-onset events are overwhelmingly persons classified as non-white (Haas Institute 2017, Pulido 2018). They reside in locations such as low-lying coastal zones, small island states, and agriculturedependent nations disproportionately exposed to hurricanes, floods, drought, desertification and rising sea levels (Anand 2004). In addition, they have been rendered socially and economically vulnerable to climate change by the North's economic and military interventions. The North's "under-development" of the global South during the colonial and postcolonial era, so eloquently described by Walter Rodney (1972) and Eduardo Galeano (1997), has been exacerbated by decades of neoliberal economic reforms imposed initially by the World Bank and the International Monetary Fund (IMF) and subsequently through regional and multilateral trade agreements and bilateral investment treaties (Gonzalez 2015). These reforms increased poverty; reduced access to health care, education, and other social services; undermined the development of climate-resilient urban and rural infrastructure; created mass displacement; and deprived states and communities of resources for climate adaptation and disaster response and recovery (Haas Institute 2017, Saad 2017).

Finally, racialized communities in the global South are being displaced not only by climate change, military interventions and neoliberal economic policies, but also by the measures deployed to mitigate greenhouse gas emissions. For example, wind farms are being developed in Oaxaca, Mexico on indigenous lands to provide energy to Walmart, 
Coca-Cola, Heineken and Cemex (a Mexican cement manufacturer) without public debate; adequate compensation; free, prior and informed consent; equitable sharing of benefits with local communities; and mechanisms to provide compensation for damage and loss to land (Baker 2015, Zárate-Toledo et al. 2019). In Canada, a controversial proposal to build an enormous hydroelectric dam on the Peace River threatens to displace indigenous peoples and replicate the sacrifice zones of carbon capitalism - this time in the name of "green energy" (Scott and Smith 2017). In Brazil and throughout the global South, forest conservation schemes developed through the climate regime's Reducing Emissions from Deforestation and Forest Degradation (REDD+) mechanism undermine the rights of local and indigenous communities to harvest plants, timber, or fish in their ancestral territories (Klein 2014, Kronk Warner 2015). Lastly, legislation in the US and the EU mandating the blending of biofuels into transportation fuels has increased food prices and incentivized large-scale land transactions in the global South that destroy forests and displace rural dwellers in order to make way for large plantations to cultivate biofuel feedstocks (such as oil palm). These mandates remain in place even though the life-cycle greenhouse gas emissions of many biofuels exceed those of the fossil fuels they replace (Gonzalez 2016).

An analysis of climate change grounded in the coloniality of power reveals a key thread that unites these abuses - the abyssal line dividing those deemed human from those deemed non-human or sub-human. While everyone is vulnerable to climate change, those who occupy the sacrifice zones of racial capitalism are particularly susceptible to harm due to their classification as sub-human and disposable. Racialization justifies and naturalizes violence and dispossession in war zones, in resource extraction zones, in the green energy economy, and in the refugee camps and migrant detention centers of the global North. As Naomi Klein candidly observes:

A culture that places so little value on black and brown lives that it is willing to let human beings disappear beneath the waves, or set themselves on fire in detention centres, will also be willing to let the countries where black and brown people live disappear beneath the waves, or desiccate in the arid heat. When that happens, theories of human hierarchy - that we must take care of our own first - will be marshalled to rationalize these monstrous decisions. (Klein 2016, p. 9)

Even though they have uprooted "the darker races" (Du Bois 1900/2007) throughout the world through the ecological and economic crises of colonialism, militarism and predatory capitalism, Northern governments use a variety of border controls to exclude "those whose very recourse to migration results from the ravages of capital and military occupations" (Walia 2013, p. 5). For those below the abyssal line, racism is not simply prejudice or discrimination, but "state-sanctioned or extralegal production and exploitation of group-differentiated vulnerability to premature death" (Gilmore 2007, p. 28).

International law has been deeply complicit in the project of racial capitalism. As Antony Anghie (2004) explains, international law originates in the colonial encounter and has been used to justify successive Northern interventions in the global South through a variety of doctrines - including terra nullius, the doctrine of discovery, the mandate system, trusteeship, modernization, development, good governance, humanitarian intervention and pre-emptive self-defense. International law has depicted Southern peoples as so primitive, savage, uncivilized, backward, and under-developed that their 
lives, livelihoods, and cultures are unworthy of protection (Anghie 2004, Gonzalez 2015). This history raises serious questions about the ability of the climate regime to secure climate justice for racialized communities displaced by climate change.

\section{Climate Justice and Climate Displacement: Evaluating the Emerging Approaches}

The concept of climate justice has been integrated, albeit partially, in the climate regime. This section examines climate justice in the UNFCCC and the Paris Agreement and evaluates the evolving legal and policy responses to climate displacement.

\subsection{Climate Justice and the Paris Agreement}

Climate activists and Southern states have long sought to incorporate climate justice into the legal instruments governing climate change by arguing that the North has incurred a climate debt for its historic and current contribution to climate change (Simms 2009). The polluter pays principle and state responsibility for transboundary harm have been invoked to provide legal support for this proposition (Govind and Verchick 2015).

In 1992, the UNFCCC implicitly recognized this climate debt by observing "that the largest share of historical and current global emissions has originated in developed countries" (preamble) and expressly adopting the principle of common but differentiated responsibilities and respective capabilities (CBDR-RC) in article 3(1). In accordance with this principle, article 3(1) of the UNFCCC directs the global North to "take the lead in combating climate change and the adverse effects thereof," and article 4 requires the North to provide financing and technology transfer to the countries of the global South.

The Paris Agreement (2015) reaffirms the principle of CBDR-RC in article 2(2), and includes references to climate justice and the rights of migrants in its preamble. However, despite these justice-friendly provisions, the Paris Agreement will not be sufficient to avoid catastrophic climate displacement. The objective of the Paris Agreement is to limit global temperature increases to well below $2^{\circ} \mathrm{C}$ in excess of preindustrial levels and to strive to limit the temperature increase to $1.5^{\circ} \mathrm{C}$ (art 2). To achieve this objective, the agreement adopts a "bottom up" approach that requires each country to determine and communicate its greenhouse gas reduction pledge, known as Nationally Determined Contributions (NDCs) (art. 3). Beginning in 2023, each country must revise and ratchet up its pledge every five years, taking into account periodic assessments of the collective progress of the parties towards the Paris Agreement's objectives (arts 4, 14).

Studies indicate that commitments in NDCs at the time of writing will result in an average global temperature increase of $3^{\circ} \mathrm{C}$ (Rogelj et al. 2016, Raftery et al. 2017). An increase of $3^{\circ} \mathrm{C}$ above pre-industrial levels will inundate many small island states, as well as submerge substantial portions of low-lying regions including Bangladesh, the Nile Delta and the Mekong Delta (IPCC 2014, Glennon 2017). It will also flood many of the world's mega-cities (including Mumbai, New York, and Shanghai) by hastening the melting of the Antarctic and Greenland ice sheets (IPCC 2014, 2019). 
Furthermore, the IPCC's 2018 special report, Global Warming of $1.5^{\circ}$, warned that even a temperature increase of $2^{\circ} \mathrm{C}$ above pre-industrial levels would be catastrophic. The report concluded that temperatures must remain below the $1.5^{\circ} \mathrm{C}$ threshold in order to avoid serious climate-related risks. This requires parties to the Paris Agreement to reduce global carbon emissions by a massive 45 percent (from 2010 levels) by 2030 and achieve net zero carbon emissions by 2050 (IPCC 2018). The United Nations Environment Programme (UNEP) has called on states to increase their NDCs five-fold in order to achieve the $1.5^{\circ} \mathrm{C}$ goal (UNEP 2019).

Unless states take aggressive action to reduce the major gap between the emissions reductions pledged and what is required to avert catastrophic climate change, the world could experience one of the largest waves of migration and displacement in modern history (UNEP 2018). Climate change is anticipated to displace as many as one billion people by 2050, both within and across national borders (Kamal 2017, n.p.). Climate change acts as a threat-multiplier that exacerbates pre-existing vulnerabilities, leaving people with little alternative but to migrate. Flooding and drought, for example, can impede access to food and water, jeopardize livelihoods, intensify poverty, and spark political unrest (Warner et al. 2009). Small Island Developing States (SIDS) are especially vulnerable to slow-onset climate-related events (such as rising sea levels, flooding and recurring drought) as a consequence of their small land mass, low elevation, and limited freshwater resources. Many are projected to vanish completely due to rising sea levels (Bank and Frölich 2018, Burkett 2018). If climate change renders SIDS uninhabitable, these states alone will contribute 65 million people to the world's total number of climate-displaced persons (Bank and Frölich 2018, p. 6, note 6).

Despite the demand by many nations in the global South (especially SIDS) for a loss and damage mechanism to provide compensation for both rapid-onset and slow-onset harms that cannot be avoided through adaptation (including climate displacement), the UNFCCC had long treated loss and damage as an aspect of climate adaptation (Verchick 2018). At COP19 in Warsaw in November 2013, the parties established the Warsaw International Mechanism for Loss and Damage to explore ways of addressing harms caused by climate change (UNFCCC 2014). For the first time in the history of the climate regime, the Paris Agreement includes a separate provision on loss and damage in addition to provisions related to mitigation and adaptation (art 8). The decision adopting the Paris Agreement instructs the Warsaw Mechanism's executive committee to create a task force to "develop recommendations for integrated approaches to avert, minimize, and address displacement related to the adverse impacts of climate change." (UNFCCC 2016, para. 49). Because this task force is in its infancy, the strategies it will propose to address climate displacement have yet to be defined and do not appear to include the comprehensive relocation and resettlement measures advocated by SIDS (Chazalnoel and Jonesco 2018). In order to guide the future development of the Warsaw Mechanism, it is useful to examine and critique leading approaches to climate displacement.

\subsection{Legal and Policy Approaches to Climate Displacement}

The lack of political will to reduce greenhouse gas emissions sufficiently to avert catastrophic climate change increases the likelihood of widespread climate displacement. Because climate-displaced persons who cross international borders currently enjoy very limited legal protection (Atapattu 2014), they routinely face 
detention, deportation, and criminal prosecution. This section examines the emerging legal and policy responses to climate displacement and evaluates them through a raceconscious decolonial climate justice perspective.

\subsubsection{The National Security Response}

Climate activists and government officials in affluent countries have depicted climatedisplaced persons as threats to national security in order to exhort states to adopt aggressive climate change mitigation measures (Methmann and Oels 2015, Dawson 2017). Regrettably, this approach stokes "deep-seated fears and stereotypes of the darkskinned, overbreeding, dangerous poor" scrambling over US border fences or landing on European or Australian shores (Hartmann 2010, p. 238). The national security approach sparks fear and hatred, resulting in the militarization of borders and the construction of walls (Baldwin 2013, Karlin 2018). Instead of promoting compassion for climate-displaced persons or recognizing common but differentiated responsibilities for climate change, the national security response classifies "climate refugees" as barbarians crashing the gates of civilization and reinforces racialized distinctions between "us and them, citizen and foreigner, friend and enemy" (Ransan-Cooper et al. 2015, p. 110).

The spectre of climate-displaced persons crossing en masse from South to North also conflicts with documented patterns of migration during the current refugee crisis. According to the United Nations High Commissioner for Refugees (UNHCR), of the 68.5 million persons forcibly displaced worldwide in 2017, approximately 40 million remain in their country of origin (UNHCR 2018, p. 2). When they cross borders, most displaced persons settle in neighboring countries in the global South, which currently host 85 percent of the world's refugees (UNHCR 2018, p. 2). Turkey provides refuge to the largest number of forcibly displaced persons, followed by Pakistan, Uganda, Lebanon, Iran, Bangladesh, and Sudan (UNHCR 2018, p. 3). With the exception of Syrians fleeing drought and conflict (Gleick 2014), these refugees are not climate-displaced persons. "Only a relatively small, albeit increasing proportion of refugees worldwide have managed to come to the Global North, mostly to Germany, France, Italy, Sweden, and the United States" (Bank and Fröhlich 2018, p. 3).

International refugee law does not currently provide legal status or protection to persons displaced internationally by climate change (Atapattu 2014). The 1951 Refugee Convention defines a refugee as a person who is outside their country of origin and unwilling or unable to return due to "a well-founded fear of being persecuted for reasons of race, religion, nationality, membership of a particular social group, or political opinion" (Convention Relating to the Status of Refugees, 1951, art 1). The adverse impacts of climate change do not generally constitute persecution based on the five enumerated categories (McAdam 2012). While some states have offered temporary protection on humanitarian grounds to persons fleeing conflict or natural disasters who do not individually face persecution (van der Vliet 2018, Atapattu 2018, Platform on Disaster Displacement 2018), temporary protection will not address the needs of climatedisplaced persons whose countries will soon become permanently uninhabitable. Furthermore, it is unlikely that most states will extend this status to climate-displaced persons given the current climate of xenophobia in Europe and elsewhere (The Week 2018). 
International human rights law expands countries' obligations beyond the refugee category by prohibiting the deportation of persons "at risk of arbitrary deprivation of life, torture, or cruel, inhuman, or degrading treatment or punishment" (van der Vliet 2018 , p. 22). Known as the principle of non-refoulement, this obligation may provide limited protection to climate-displaced persons. In a landmark ruling issued in January 2020, the United Nations Human Rights Committee concluded that the adverse effects of climate change may violate Article 6 (right to life) and Article 7 (prohibition on torture or cruel and degrading treatment) of the International Covenant on Civil and Political Rights (ICCPR) - thereby triggering the proscription on deportation (UN Human Rights Committee 2020, para. 9.11). However, the Committee concluded that the petitioner's deportation from New Zealand did not violate his rights because his home country of Kiribati will not become uninhabitable for ten to fifteen years, leaving sufficient time for the government of Kiribati, with international assistance, to protect its population (UN Human Rights Committee 2020, para. 9.12). While this case is a ground-breaking ruling on the responsibility of states to climate-displaced persons, the decision raises questions about how dire conditions must be in climate-vulnerable countries before the nonrefoulement obligation applies.

Instead of providing a safe haven for refugees, the US, Europe and Australia are increasingly criminalizing migration and erecting greater barriers to entry, including enhanced sea, air and land patrols, drone surveillance, and President Trump's infamous border wall (Dawson 2017, Karlin 2018). Between January 2014 and October 2019, more than 15,000 migrants perished trying to cross the Mediterranean to Europe (IOM 2020). Migrants who do manage to traverse the North's militarized borders are frequently locked up in detention facilities, denied legal representation and required to prove their eligibility for political asylum by documenting their well-founded fear of persecution in their country of origin (Dawson 2017). In the United States, for example, migrant children as young as three years old have been compelled to represent themselves in deportation proceedings without legal counsel and without their parents who could explain the conditions in their home country that caused them to flee (Jewett and Luthra 2018).

Some scholars have proposed amending or liberally re-interpreting the 1951 Refugee Convention (or adding a new protocol) to cover climate-displaced persons (Pérez 2018). However, states have generally resisted this approach as migration policy grows more contentious in every country, especially in the global North (Jakobsson 2018). Furthermore, people rarely migrate exclusively due to environmental reasons (Atapattu 2014). Even if states agreed to provide refugee-like protection to climate-displaced persons, these "climate refugees" would undoubtedly encounter the obstacles described above - increasingly militarized borders, confinement in detention centers, lack of legal representation, and the impossible burden of demonstrating that their multi-faceted and complex decision to migrate can be attributed solely to climate change. Both international refugee law and international human rights law apply only to persons who have already reached the destination country; require proof of individualized harm rather than generally adverse conditions in the home country; and provide protection only when the harm is so severe that threats to human life are imminent (McAdam 2012). These approaches are ill-suited to the mass relocation that may be necessary to protect climate-vulnerable persons from the ravages of climate change. 
The national security response reinforces the abyssal divide by stoking fear, racism and xenophobia. It constructs climate-displaced persons as threats to the public order and increases their vulnerability to state-sanctioned premature death in detention camps, on the high seas, and in the dangerous migrant routes from Southern to Northern states. The politics of nationalism, border control, and surveillance stimulate the "desire for an enemy, the desire for apartheid, for separation and enclosure" and ultimately "the phantasy of extermination" (Mbembe 2016, p. 1).

The national security response obscures the relationship between migration and global environmental change and forecloses collaborative approaches to reverse historic and current injustices. A community's susceptibility to climate-related disasters is a function of its exposure to environmental hazards and its social and economic vulnerability (Govind and Verchick 2015). The North increased the South's exposure to environmental hazards through its profligate emission of greenhouse gases. It impoverished the South and created the social and economic conditions for mass displacement through genocide, slavery, colonialism, military interventions, and the post-World War II neoliberal economic order. Instead of questioning the economic system that subordinates and dehumanizes large segments of the world's population, the national security response serves as a vehicle for further dehumanization.

\subsubsection{The Humanitarian Response}

A second response to climate displacement depicts displaced persons as passive and helpless victims of natural disasters who need to be rescued by the international community as a form of charity rather than as a matter arising from common but differentiated responsibilities for climate change (Ransan-Cooper et al. 2015). The paradigmatic example is the portrayal of Small Island Developing States (SIDS) as vulnerable, isolated, poor, underdeveloped, and in danger of imminent extinction (Bank and Fröhlich 2018, Walshe and Stancioff 2018).

The humanitarian response exacerbates climate injustice by creating an "eco-colonial" narrative that casts the global North as the saviour of the world's disenfranchised while ignoring the North's current and historic contribution to poverty and environmental degradation (Santos 2014, Ransan-Cooper et al. 2015, Kelman 2018). By ignoring common but differentiated responsibilities for climate change or the legacy of slavery, colonialism and postcolonial economic and political interventions, the humanitarian approach obscures the North's responsibility for causing climate change and creating the social and economic conditions that lead to displacement. It portrays climate-displaced persons as victims of misfortune rather than targets of systemic immiseration, and casts Northern assistance to the states and peoples of the global South as charity rather than legal or moral reparations. The humanitarian approach reinforces the abyssal line by portraying the South as primitive, backward and in need of rescue, and by failing to address the underlying systemic causes of poverty, racism, and environmental degradation.

The humanitarian frame also disregards how migrants understand their own experiences and may deprive them of the opportunity to exercise self-determination with respect to potential strategies for responding to climate change (Ransan-Cooper et al. 2015, Bank and Fröhlich 2018). For example, Pacific islanders have generally rejected 
the label of helpless victims or climate refugees, and have emphasized their long history of resilience in the face of social and environmental challenges, their preference for in situ adaptation, and their right to determine when, whether, where, and on what terms they will migrate (Walshe and Stancioff 2018, Kelman 2018).

The Nansen Initiative (2015) is an example of a voluntary framework for disaster displacement based on the humanitarian approach. The Initiative is the only legal framework that sets out a series of principles to protect and assist displaced persons who cross international borders due to disasters, including those related to climate change (Atapattu 2018). Introduced by Norway and Switzerland in 2012, the Nansen Initiative was endorsed by more than one hundred governmental delegates in Geneva in 2015 (Platform for Disaster Displacement 2018). Its recommendations are currently being implemented by its successor, the Platform on Disaster Displacement, which focuses on integrating effective practices on cross-border disaster displacement into existing legal frameworks rather than developing a new treaty (McAdam 2016).

While the Nansen Initiative is a significant advance relative to the national security response, its approach to climate displacement is problematic in several respects. First, its charity-based approach is inconsistent with climate justice because it depoliticizes climate displacement by obscuring the North's historic responsibility for climate change and its ongoing obligation to mitigate its emissions and provide reparation for the resulting harms. Climate displacement is an injustice, "not a random, faultless act of God" (Burkett 2018, p. 82). Second, the Nansen Initiative's reliance on the voluntary implementation by states of humanitarian protection measures is likely to fail at a time when Northern states are turning away large numbers of displaced persons, including refugees fleeing conflicts in Afghanistan, Iraq, Syria and elsewhere initiated or supported by the North. Third, the Initiative's state-led approach may neglect the priorities and perspectives of climate migrants (such as loss of land, community cohesion and cultural identity), thereby raising procedural justice issues (McAdam 2012, Burkett 2018). Finally, the Nansen initiative applies only to displacement caused by severe weather events and may therefore not protect those who migrate due to slow-onset events such as desertification, flooding, and sea level rise (Atapattu 2018).

Whereas the Nansen Initiative addresses the plight of displaced persons after disaster have occurred, another humanitarian initiative - the Sendai Framework for Disaster Risk Reduction - fosters international cooperation to mitigate disaster risks, including climate displacement, before they occur (Sendai Framework 2015). While this framework introduces certain important innovations, including its community-based, bottom-up approach to disaster risk reduction and its emphasis on socio-economic vulnerability, the Sendai Framework, like its predecessor Hyogo Framework, is also based on the Northern charity rather than historic responsibility and is therefore inconsistent with a climate justice approach (Govind and Verchick 2015).

\subsubsection{The Migration Management Response}

The third response to climate displacement is migration management, which consists of state-governed regulation of mobility to prevent uncontrolled mass migration (Scott and Smith 2017). This approach is advocated by the International Organization for Migration $(\mathrm{IOM})$, whose mission includes "meeting the growing operational challenges of 
migration management" while upholding "the human dignity and well-being of migrants" (IOM; see https://www.iom.int/mission).

The migration management response promotes migrant worker programs in the global North as a means of fostering economic development and climate resilience in the global South. Instead of depicting climate-displaced persons as helpless victims or threats to national security, the migration management approach portrays them as entrepreneurs engaged in self-help who enhance the resilience of their communities by taking jobs abroad and sending home remittances (Felli 2013, Methmann and Oels 2015). Rather than treating displacement as a tragedy to be avoided, temporary labour migration is celebrated as a climate adaptation strategy that improves the lives of family members left behind and promotes "climate-smart" development as long as the migration process is carefully controlled by states and by institutions of global governance (Methmann and Oels 2015, Bettini et al. 2017).

The migration management approach imposes the burden of climate change adaptation on the planet's most climate-vulnerable populations instead of requiring the North to finance climate change adaptation and prevent displacement in the global South (Methmann and Oels 2015, Bettini et al. 2017). As Felli pointedly observes:

Whereas climate refugees were depicted as (potential) helpless victims of climate change-induced forced migration, the language of climate migration as adaptation radically transforms the location of social agency and, consequently, the responsibility for climate change consequences. Rather than understanding 'climate refugees' as victims of climate change produced by industrialized countries, and thus as in need of justice (which could take the form of funding for adaptation), these individuals are turned, through a 'positive story', into entrepreneurial migrants who not only can lift themselves out of poverty but may also contribute to the 'resilience' of their 'vulnerable' communities. (Felli 2013, p. 350)

Furthermore, as noted by the UN Special Rapporteur on the Situation of Human Rights Defenders in his special report on people on the move, the migration management response treats climate displaced persons as "commodities to be exploited in the national labour market (...) on terms not dissimilar to other inputs in the production process" (UN Human Rights Council 2018, p. 9, para. 27). Because the migration management approach does not obligate the North to open its borders to climate-displaced persons, it is likely to subject climate migrants to the vicissitudes of Northern labour markets. Migrants who are young, able-bodied, light-skinned and skilled will be favoured while the vast majority (darker, poorer, older, disabled) will be classified as "illegal," treated as disposable, and thrust below the abyssal line. Because the migration management approach does not require Northern states to grant these migrants labour rights and social safety nets (including the right to complain or protest without running the risk of deportation), there is a risk that temporary workers with legal status and undocumented workers will be abused, cheated, and exposed to unsafe and exploitative working conditions (Felli 2013, UN Human Rights Council 2018). Although the International Convention on the Protection of the Rights of all Migrant Workers and Members of their Families (1990) protects the rights of migrant workers in principle, the affluent, labourimporting states of the global North have neither signed nor ratified this treaty (UNHCHR 2019). 
Finally, migration can intensify climate vulnerability in migrants' home countries to the extent that the exodus of able-bodied workers produces a brain drain, labour shortages and reliance on erratic remittance flows (Ransan-Cooper 2015). Indeed, the migration management approach may exacerbate the vulnerability of "trapped populations" who do not have the resources to participate in international labour markets or the means to move out of vulnerable geographic locations (Methmann and Oels 2015). These "trapped populations" are likely to include a disproportionate number of women, children, the elderly, the poor, and the disabled (Willcox 2016, Sorensen et al. 2018).

Proponents of the migration management approach have suggested planned relocation as one solution to the potential immobility of vulnerable communities (Methmann and Oels 2015). Planned relocation consists of the voluntary or compulsory resettlement of persons living in hazardous locations to prevent displacement due to climate-related disasters or to relocate those who have already been displaced (Scott and Smith 2017). In 2010, at COP16 in Cancun, the parties adopted the Cancun Climate Adaptation Framework, which endorses the migration management approach, including planned relocation (Warner 2012). At the insistence of the US, the parties replaced the term "climate refugees" as a subject of adaptation-related cooperation among the parties with the phrase "climate change induced displacement, migration and planned relocation" (Warner 2011). The reference to planned relocation, which is itself a form of displacement, suggests that states increasingly view compulsory resettlement as a form of climate change adaptation.

Planned relocation raises significant human rights concerns. Vulnerable communities in the global South have frequently been compelled to relocate to accommodate large-scale infrastructure projects such as hydroelectric dams, highways, and mines (Scott and Smith 2017, Bank and Fröhlich 2018). "The impacts on the lives of people driven from their homes by such ventures can be just as severe in scope and duration as those experienced by people displaced by conflict, violence and disasters" (Walicki and Swain 2016, p. 8). These impacts include not only the loss of lands, livelihoods and social cohesion, but also the forfeiture of connections to places essential to the community's spiritual and cultural identity (Scott and Smith 2017). This history of planned relocation should serve as a cautionary note about the dangers of top-down governmental decisionmaking. Consistent with the requirements of procedural justice, it is important to ensure that community members are well-informed of the options, have a sense of control over the destination and the process of movement, and provide their full, prior, and informed consent. Whether the benefits of moving outweigh the costs is a highly political decision best left to the affected community (Methmann and Oels 2015).

In sum, the migration management approach enables the North to limit and control the movement of climate-displaced persons by portraying climate-induced temporary labour migration as an economic opportunity for a select group of "entrepreneurial" migrants. The classification of these climate-displaced persons as economic migrants justifies the denial of refugee status under the 1951 Refugee Convention. It absolves the North of responsibility for climate change and for structural injustices caused by racial capitalism that increase vulnerability to displacement. The migration management approach reinforces the abyssal line by allowing the North to selectively admit a small 
number of "worthy" migrants while consigning the vast majority to "illegality," immobility, or forced relocation.

\section{A Just Approach to Climate Displacement?}

The national security, humanitarian, and migration management responses reinforce the abyssal divide by casting the North as superior and civilized while invoking the spectre of disorderly, disruptive, dark-skinned migrant invaders. These frameworks reflect a "desire to preserve the apparent normalcy of an imagined social order that the monstrous, future-conditional climate change migrant threatens to overwhelm" (Baldwin 2016, p. 81). Without making an explicit reference to race, these responses suggest that the future of white supremacy depends on its ability to manage and contain the teeming masses from the South that climate change threatens to unleash. Indeed, some scholars have observed that the discourse on climate change and migration weaponizes fear and could produce a "pre-emptive race war in which the survival of one population is pursued at the expense of another" (Baldwin 2016, p. 86). Arguably, elements of this race war have already begun on the borders of the US, Australia, and the EU.

An analysis grounded in racial capitalism must address the question of who benefits from the policies that stoke racism and militarize borders. There appear to be at least six distinct groups of beneficiaries. The most immediate beneficiaries are the corporations that contract with governments to provide highly lucrative security, surveillance, border wall construction, and privately operated prisons and detention facilities (Lowenstein 2015, Olivares 2016, Bhattacharyya 2018). A second set of beneficiaries consists of state security apparatuses whose staff and budget swell in order to administer the detention and expulsion of ever-growing numbers of migrants (Bhattacharyya 2018). A third group of beneficiaries includes the businesses which gain economically when detained migrants are forced to provide low-paid, indentured labour akin to that performed by persons incarcerated for criminal offenses (Richards and Peña 2017). These businesses also benefit from temporary migration schemes and from the exploitation of undocumented workers. A fourth group of beneficiaries comprises states in geographical proximity to Northern states (transit states such as Mexico, Libya and Morocco) which are able to obtain monetary compensation, political concessions or trade benefits by agreeing to limit the movement of migrants (Bhattacharyya 2018). A fifth group of beneficiaries consists of criminal enterprises that specialize in the trafficking of undocumented migrants and can charge higher fees as border controls increase (Wood 2018). Finally, authoritarian demagogues in the global North benefit from stoking hatred of migrants and other racialized groups in order to create a wedge between economically subordinated groups. By demonizing migrants and other racialized groups, these demagogues secure the support of working class whites for policies that intensify economic inequality, destroy social safety nets, and hasten catastrophic climate change (Hochschild 2016, Bhattacharyya 2018, Metzl 2019).

In an insightful and provocative article titled Human Rights and Root Causes, Susan Marks (2011) analyzes the perils of treating human rights abuses as random misfortunes that can be remedied if only perpetrators adopted better practices, laws and policies. She calls for an examination of the systemic causes of injustice, and argues that scholars and activists should spend less time pursuing state-oriented reforms that demobilize 
oppositional activity and more time channeling grievances into organized and coherent action.

A race-conscious decolonial narrative of climate justice that examines the cradle-to-grave impacts of carbon capitalism has the potential to unite diverse and powerful social movements that reject militarism, extractivism, economic inequality and racism. As Naomi Klein observes, social justice struggles are often compartmentalized:

The anti-austerity people rarely talk about climate change, the climate change people rarely talk about war or occupations. We rarely make the connection between the guns that take black lives on the streets of US cities and in police custody and the much larger forces that annihilate so many black lives on arid land and in precarious boats around the world. (Klein 2016, p. 10)

The expansive concept of climate justice articulated in Section 2 of this article, including the notion of the racialized abyssal line, can serve as the glue that holds these diverse social movements together and provides a framework for transnational mobilization.

In order to achieve climate justice, it is also necessary to develop legal approaches to climate displacement around which social movements and climate-vulnerable states can coalesce in order to push back against the national security, humanitarian, and migration management approaches. Scholars have long recognized that international law is constrained as a tool of resistance due to its epistemological complicity with structural violence against humans and non-human nature (Lindgren 2018). Influenced by Enlightenment philosophers, international law universalized the idea that humans are obligated to dominate nature, and created racial hierarchies that justify the objectification, dehumanization, dispossession, and exploitation of societies that differ from Euro-American norms. Moreover, the Western legal model's individualistic focus is ill-equipped to recognize and remedy systemic injustice (Gonzalez 2015).

Despite these limitations, international law can be used in counterhegemonic ways by social movements in the global South (Rajagopal 2003). Indeed, decolonial theory's emphasis on the "critical anti-Eurocentric epistemological standpoint of colonial migrants and subjects" (Grosfoguel et al. 2014, p. 13) suggests that solutions to the problem of climate displacement are best developed by listening to and critically engaging with those who are displaced. For example, the People's Agreement that emerged from the 2010 World People's Conference on Climate Change and the Rights of Mother Earth in Cochabamba, Bolivia, unequivocally calls upon Northern states to:

assume responsibility for the hundreds of millions of people that will be forced to migrate due to the climate change caused by these countries, and eliminate their restrictive immigration policies, offering migrants a decent life with full human rights guarantees in their countries. (People's Agreement 2010, n.p.)

One approach to climate displacement that has emerged from Southern states and communities is the collective right of displaced peoples to self-determination (Pascoe 2015, Willcox 2016, Maguire and McGee 2017). Self-determination is the right of subordinated peoples to control their own destiny rather than having it imposed on them by foreign powers (Williams 1991). The collective right of peoples to selfdetermination is recognized in common Article 1 of the International Covenant on Civil and Political Rights (ICCPR 1966) and the International Covenant on Economic, Social and Cultural Rights (ICESCR 1966); the United Nations General Assembly Declaration 
on the Granting of Independence to Colonial Countries and Peoples (1960); and the United Nations Declaration on the Rights of Indigenous Peoples (UNDRIP 2007).

Instead of portraying climate-displaced persons as barbarians, passive victims or entrepreneurs, the self-determination approach recognizes climate-vulnerable states and peoples as political subjects capable of collectively determining their own fates (RansanCooper et al. 2015). The self-determination approach is designed to foster the collective right of states and peoples to preserve their cultural integrity and community cohesion so as to migrate with dignity (Klepp and Herbeck 2016). As Ross points out in connection with the migration of I-Kiribati and Tuvaluans to New Zealand:

Being forced to move to New Zealand might end up as a kind of inverse colonisation: instead of the coloniser coming to peoples and forcing them to assimilate the coloniser's culture, peoples now have to come to another society and integrate into that society's culture. (Ross 2017, n.p.)

Self-determination is a process rather than a pre-determined outcome. In the South Pacific, for example, postcolonial thinkers have pointed out that active travel between the islands was the norm in Oceania prior to the imposition of colonial borders and have called for new forms of transnational solidarity and new models of citizenship that transcend "the model of citizenship of the Peace of Westphalia" (Klepp and Herbeck 2016, p. 71). This means that in situ adaptation and labour migration to nearby states should not be the only options available to small island communities. Other options include ex situ reconstitution of the state on the territory of another state; selfgovernment as an autonomous administrative unit of another state (akin to a state or province); and self-governance as a minority group within the territory of another state - all premised on the willingness of states to cede territory to displaced peoples (McAdam 2012). The self-determinations approach calls for consultative, inclusive, place- and culture-specific processes that provide resources to support migrants' mobility decisions (Ransan-Cooper et al. 2015).

The self-determination approach attempts to bridge the abyssal line by empowering climate migrants and facilitating collective decision-making on migration. Concerned that a multilateral treaty on climate displacement "may not respond to communities' human rights concerns, especially those relating to cultural integrity, self-determination, and statehood" (McAdam 2012, p. 199), many vulnerable states and indigenous peoples are calling for bilateral and regional approaches to climate change-related migration that respond to unique local needs; reflect common histories, traditions, and social structures; and respect their right to exist as self-governing communities (McAdam 2012, Corendea 2018). Regional negotiations in the Pacific might inaugurate new migration-friendly approaches based on self-determination that call into question traditional conceptions of sovereignty and the nation state (Klepp and Herbeck 2016).

The self-determination approach is not limited to the small island states, whose entire territory may be rendered uninhabitable by rising sea levels. It can also be adopted by climate-displaced persons in low-lying states like Bangladesh and Vietnam which will lose large portions of territory and by people displaced by drought and desertification. The right to self-determination gives climate-vulnerable communities the option to migrate collectively in order to preserve their language, culture, customs, and selfgoverning political community (Wyman 2017). 
The right to self-determination is by no means a panacea for climate displacement. It implies a correlative duty on other states (such as high-emitting former colonial powers) to accommodate displaced communities, which will undoubtedly engender controversy and fierce resistance (Wyman 2017). The right may be re-interpreted and depoliticized by the global North as a collective self-help project that requires communities facing displacement to purchase land in other countries and finance their migration with no assistance from high-emitting countries. It also faces internal challenges, such as the heterogeneity of climate-displaced communities (including gender, class and other intersectional divisions) and the need to develop mechanisms to resolve conflicts about adaptation and migration pathways. Finally, in order to ensure justice for all migrants, the right to self-determination must be complemented by the North's responsibility to welcome climate-displaced persons who elect to migrate individually rather than collectively. One vehicle that has been proposed to facilitate individual migration is the issuance of passports for the territorially dispossessed (modelled on the Nansen passports issued by the League of Nations) that allow climate migrants to choose where to resettle and require all states to accept these passport holders and permit them to become naturalized citizens (Heyward and Ödalen 2016).

The self-determination approach must necessarily be premised on a responsibility-based framework that "defines special obligations resulting from the wrongful conduct of some states that harms other states" (van der Vliet 2018, p. 24). Drawing upon several principles of international environmental law, including CBDR-RC, the polluter pays principle, and the precautionary principle (all of which are reflected in the climate regime), a responsibility-based legal framework would emphasize the duty of highemitting states to prevent displacement by reducing their own greenhouse gas emissions and by providing climate-vulnerable states with the technical and financial resources for climate adaptation and disaster risk reduction. If these measures do not forestall the need to relocate, then persons at risk of climate displacement should have the right to migrate to other countries in numbers proportionate to those countries' responsibility for climate change (Byravan and Rajan 2006). For example, Michael Gerrard argues that highemitting states should open their borders to climate-displaced persons based on each country's historic contribution to climate change (Gerrard 2015). Using carbon dioxide emissions from 1850 to 2011, he concludes that the US and the EU would be responsible for resettling over half of all climate-displaced persons. A responsibility-based legal framework grounded in self-determination should require high-emitting states to finance and facilitate the mobility decisions of climate-vulnerable people rather than dictating the terms and destination of migration. This obligation to finance and facilitate migration would include providing land, furnishing relocation assistance, and ensuring that climate-displaced persons enjoy access to livelihoods, healthcare, housing, education, and the ability to protect their languages, cultures, and traditions of selfgovernance.

A responsibility-based approach should also take into account the degree to which Northern states have contributed to the climate vulnerability of Southern states and peoples. As one observer points out:

The nature of the wrong here is that the ability of some actors to adapt to climate change is low due to historical legacies of injustice, which would include those of colonial policy (economic underdevelopment, weak governance structurers, arbitrary borders, 
poor infrastructure), Cold War politics (e.g., destabilizing and/or deposing democratically elected regimes, proxy wars, small arms proliferation), and neoliberal structural adjustment programs (defunding of the public sector, structurally disadvantageous trade agreements that lock in underdevelopment). (Saad 2017, p. 100)

Migration law scholar E. Tendaye Achiume argues that Northern states have a legal and moral duty to accept migrants from Southern states as a form of corrective justice for colonial and post-colonial interventions that impoverished Southern states and peoples and deprived them of the capacity for self-determination (Achiume 2019). She maintains that the exclusion of Southern migrants is fundamentally unjust given the imperial interconnection and interdependence between Northern and Southern states. In addition, as I have argued elsewhere, the duty to accept migrants flows from the North's violation of the customary international law obligation to refrain causing transboundary harm. Specifically, Northern states devastated Southern lives and livelihoods by maintaining an international economic order that produces "harmful impacts on wages, prices, employment, social services (...), human health, and access to environmental necessities, such as food, land, and water" (Gonzalez 2011, p. 787).

In sum, the self-determination response is inextricably intertwined with a responsibilitybased approach that seeks to impose obligations on Northern states based on their contribution to both climate change and climate vulnerability. An approach to climate justice that takes into account the factors that produce climate vulnerability (including the North's historic and ongoing immiseration of the South through military, political, and economic interventions) avoids the environmental determinism that characterizes many debates over climate displacement by acknowledging the complex, multi-faceted drivers of migration (McAdam 2012). The self-determination approach also expands our understanding of climate justice to include cognitive or epistemic justice - centering the experiences and perspectives of subordinated peoples rather than imposing Eurocentric solutions (Fricker 2007, Tsosie 2012, Santos 2018).

While a full analysis and critique of the self-determination approach is beyond the scope of this paper, it is one example of a response to climate displacement that attempts to subvert the abyssal divide by emphasizing the agency and diverse place-based perspectives of subaltern communities. Instead of treating climate-displaced persons as objects (savages, victims or exploitable workers), the self-determination approach embraces their agency, their creativity, and their ability to devise ways to preserve their lives, livelihoods, cultures and ways of life in the face of catastrophic climate change. If embedded in a legal framework that imposes obligations on states to accept climatedisplaced persons and to make resources available to them as reparation for the legacy of colonial and post-colonial dispossession, this approach may permit people to shape their own history and potentially to transcend colonial borders that impose immobility and increase climate vulnerability. The self-determination approach is an example of the ways that Southern states and peoples can infuse the climate regime with different values, perspectives and solutions that redeploy existing legal principles in the interest of subaltern communities and climate justice.

\section{Conclusion}

Racialized communities have borne the brunt of carbon capitalism from its origins in genocide and slavery to the contemporary climate crisis and are increasingly being 
displaced by the emerging green energy economy. Their location below the abyssal line subjects these communities to the "slow violence" of the extractive and polluting fossil fuel industry (Nixon 2013); resource wars; predatory economic policies; climate-induced disasters; and criminalization, detention, and state-sanctioned death when they attempt to cross the militarized borders of the global North. Viewing climate change as an environmental issue unrelated to other social justice struggles fosters environmental determinism, erases history, and conceals the multiple and inter-related injustices of carbon capitalism.

Communities below the abyssal line are the canaries in the coal mine. They are the first to suffer the ravages of climate change, and their plight is a harbinger of the harm that will befall everyone. Racism creates divisions between groups of people whose vulnerability to carbon capitalism should serve as the basis for solidarity. As economic inequality increases and the planet's ecosystems are brought to the brink of collapse, all but the very affluent will become frontline communities in an increasingly damaged and dangerous world.

A concept of climate justice grounded in racial capitalism can bring together diverse social movements by articulating the links between extractivism, poverty, racism, economic inequality, environmental degradation, displacement, mass incarceration, police brutality, immigrant detention/deportation, militarism, indigenous dispossession, and a global economic order that systematically subordinates the global South and undermines the livelihoods of many in the global North. As Martin Luther King, Jr. noted decades ago, "[i]njustice anywhere is injustice everywhere (...). In a real sense all life is inter-related" (King 1963, n.p.). Only through collective struggle can genuinely emancipatory solutions be achieved.

Racialization undermines solidarity by portraying large segments of humanity as inferior, unworthy, expendable and as threats to national security. Nowhere is this more evident than in the inhumane response of Northern countries to migrants fleeing conflict, persecution, poverty, and environmental degradation. As climate change increases the flow of migrants, Northern states are imposing solutions that reinforce national borders, intensify the abyssal divide, and absolve the North of responsibility for its prodigious carbon emissions and its current and historic subordination of the South. The scapegoating of migrants for the economic and ecological crises of capitalism impedes resilience and restricts mobility. This replicates historical patterns of confining colonized and enslaved peoples to particular locations while encouraging the mobility of colonizers. It is also eerily reminiscent of Garrett Hardin's "lifeboat ethics" - the notion that the affluent should toss the (racialized) poor overboard in order to keep their own heads above water (Hardin 1974/2015).

The climate crisis calls into question the sanctity of national borders and poses a fundamental challenge to the collapsing sovereign-centric Westphalian system. As current migration trends reveal, people will not sit still in the face of climate catastrophe. They will relocate, adapt, improvise, cross borders and find other ways of surviving and rebuilding their lives. Solutions premised on detaining and expelling climate-displaced persons have little chance of succeeding. The task ahead is to decolonize colonial notions of nationalism and fortified borders and to recognize the rights of climate-displaced persons to migrate collectively and individually. A legal framework based upon the 
largely unfettered right of states to exclude migrants is ill-suited to the achievement of climate justice.

\section{References}

Achiume, E.T., 2019. Migration as Decolonization. Stanford Law Review [online], 71(6), 1509-1574. Available from:

https://www.stanfordlawreview.org/print/article/migration-as-decolonization/ [Accessed 8 June 2020].

Anand, R., 2004. International Environmental Justice: A North-South Dimension. Farnham: Ashgate.

Anghie, A., 2004. Imperialism, Sovereignty and the Making of International Law. Cambridge University Press.

Atapattu, S.A. 2014. Climate Change: Disappearing States, Migration, and Challenges for International Law. Washington Journal of Environmental Law \& Policy [online], 4(1), 1-35. Available from: https://digitalcommons.law.uw.edu/wjelp/vol4/iss1/3 [Accessed 8 June 2020].

Atapattu, S.A., 2018. A New Category of Refugees?: "Climate Refugees" and a Gaping Hole in International Law. In: S. Behrman and A. Kent, eds., Climate Refugees: Beyond the Legal Impasse? New York: Routledge, 34-51.

Baker, S.H., 2015. Project Finance and Sustainable Development in the Global South. In: S. Alam et al., eds. International Environmental Law and the Global South. New York: Cambridge University Press, 338-355.

Baldwin, A., 2013. Racialisation and the Figure of the Climate Change Migrant. Environment and Planning A [online], 45(6), 1474-1490. Available from: https://doi.org/10.1068/a45388 [Accessed 8 June 2020].

Baldwin, A., 2016. Premeditation and white affect: climate change and migration in critical perspective. Transactions of the Institute of British Geographers [online], 41(1), 78-90. Available from: https://doi.org/10.1111/tran.12106 [Accessed 8 June 2020].

Bali Principles of Climate Justice, 2002 [online]. Johannesburg: International Climate Justice Network, 29 August. Available from: https://www.ejnet.org/ej/bali.pdf [Accessed 15 May 2019].

Bank, A., and Frölich, C., 2018. Forced Migration in the Global South: Reorienting the Debate. GIGA Focus [online], nº. 3. June. German Institute of Global and Area Studies. Available from: https://www.giga-hamburg.de/en/publication/forcedmigration-in-the-global-south-reorienting-the-debate [Accessed 15 May 2019].

Baskin, J., 2019. Global Justice and the Anthropocene: Reproducing a Development Story. In: F. Biermann and E. Lövbrand, eds., Anthropocene Encounters: New Directions in Green Political Thinking. Cambridge University Press, 150-168.

Beckert, S., 2014. Empire of Cotton: A Global History. New York: Alfred A. Knopf.

Bettini, G., Nash, S.L., and Gioli, G., 2017. One step forward, two steps back? The fading contours of (in)justice in competing discourses on climate migration. The 
Geographical Journal [online], 183(4), 348-358. Available from:

https://doi.org/10.1111/geoj.12192 [Accessed 8 June 2020].

Bhattacharyya, G., 2018. Rethinking Racial Capitalism. London/New York: Rowman \& Littlefield.

Birnbaum, M., 2017. Could the flow of migrants to Europe be stopped? Washington Post [online], 3 October. Available from:

https://www.washingtonpost.com/world/europe/could-the-flow-of-migrants-toeurope-be-stopped/2017/10/02/e76ac66e-a2ce-11e7-b573-

8ec86cdfeled story.html?utm term $=.6165 \mathrm{~b} 4 \mathrm{~d} 41 \mathrm{a} 80$ [Accessed 15 May 2019]

Blackburn, R., 1997. The Making of the New World Slavery. London: Verso.

Boghani, P., 2018. The "Human Cost" of the EU's Response to the Refugee Crisis. Frontline [online], 23 January. Available from:

https://www.pbs.org/wgbh/frontline/article/the-human-cost-of-the-eus-responseto-the-refugee-crisis/ [Accessed 15 May 2019].

Brodkin, K., 1998. How Jews Became White Folks and What that Says About Race in America. New Brunswick: Rutgers University Press.

Burkett, M., 2009. Climate Reparations. Melbourne Journal of International Law [online], 10(2), 509-543. Available from:

http://classic.austlii.edu.au/au/journals/MelbJIL/2009/29.html [Accessed 8 June 2020].

Burkett, M., 2018. Justice and Climate Migration. In: S. Behrman and A. Kent, eds. Climate Refugees: Beyond the Legal Impasse? New York: Routledge, 73-88.

Byravan, S., and Rajan, S.C., 2006. Providing New Homes for Climate Change Exiles, Climate Change Policy [online], 6(2), 247-252. Available from:

https://doi.org/10.1080/14693062.2006.9685599 [Accessed 8 June 2020].

Center for International Environmental Law (CIEL) and The Global Initiative for Economic, Social and Cultural Rights (GIESCR), 2018. States' Human Rights Obligations in the Context of Climate Change [online]. Available from: https://www.ciel.org/wp-content/uploads/2018/01/HRTBs-synthesis-report.pdf [Accessed 15 May 2019].

Center for International Environmental Law (CIEL) and The Global Initiative for Economic, Social and Cultural Rights (GIESCR), 2019. States' Human Rights Obligations in the Context of Climate Change: 2019 Update [online]. Available from: https://www.ciel.org/wp-content/uploads/2019/03/HRTB-Feb.-2019-update-201903-25.pdf [Accessed 4 April 2019].

Chalabi, M., 2018. How many migrant children are detained in US custody? The Guardian [online], 22 December. Available from:

https://www.theguardian.com/news/datablog/2018/dec/22/migrant-children-uscustody [Accessed 4 April 2019].

Chazalnoel, M.T., and Jonesco, C., 2018. Advancing the Global Governance of Climate Migration through the United Nations Framework Convention on Climate 
Change and the Global Compact on Migration. In: S. Behrman and A. Kent, eds. Climate Refugees: Beyond the Legal Impasse. New York: Routledge, 103-177.

Chen, M., 2018. Trump's caravan problem isn't which people are coming, but what kind of country America will choose to be. NBC News, Think [online], 10 December. Available from: https://www.nbcnews.com/think/opinion/trump-scaravan-problem-isn-t-which-people-are-coming-ncna945816 [Accessed 15 May 2019].

Collinson, S., 2019. Trump seems inclined to close border despite potential chaos. CNN [online], 2 April. Available from: https://www.cnn.com/2019/04/02/politics/donald-trump-immigration-borderclosure-crisis/index.html [Accessed 15 May 2019].

Convention for the Protection of the Rights of All Migrant Workers and Members of their Families, 1990. (GA res. 45/158, annex, 45 U.N. GAOR Supp. (No. 49A) at 262, UN Doc. A/45/49) entered into force 1 July 2003.

Convention Relating to the Status of Refugees, 28 July 1951 (189 U.N.T.S. 137), entered into force 22 April 1954.

Corendea, C., 2018. Regionalism, human rights and migration in relation to climate change. The Conversation [online], 28 February. Available from:

http://theconversation.com/regionalism-human-rights-and-migration-in-relationto-climate-change-90129 [Accessed 15 May 2019].

Crenshaw, K., 1989. Demarginalizing the Intersections of Race and Sex: A Black Feminist Critique of Antidiscrimination Doctrine, Feminist Theory, and Antiracist Politics. University of Chicago Legal Forum [online], 1989(1), 139-167. Available from: http://chicagounbound.uchicago.edu/uclf/vol1989/iss1/8 [Accessed 8 June 2020].

Crutzen, P.J., and Stoermer, E.F., 2000. The "Anthropocene." Global Change Newsletter, $41,17-18$.

Cummings-Bruce, N., 2018. Taking Migrant Children from Parents is Illegal, U.N. Tells U.S. New York Times [online], 5 June. Available from:

https://www.nytimes.com/2018/06/05/world/americas/us-un-migrant-childrenfamilies.html [Accessed 8 June 2020].

Davidson, H., 2016. Offshore detention: Australia's recent immigration history a "human rights catastrophe". The Guardian [online], 13 November. Available from: https://www.theguardian.com/australia-news/2016/nov/13/offshore-detentionnauru-immigration-history-human-rights [Accessed 15 May 2019].

Davis, H., and Todd, Z., 2017. On the Importance of a Date, or Decolonizing the Anthropocene. ACME: An International Journal of Critical Geographies [online], 16(4), 761-780. Available from: https://www.acmejournal.org/index.php/acme/article/view/1539 [Accessed 8 June 2020].

Dawson, A., 2017. Extreme Cities: The Peril and Promise of Urban Life in the Age of Climate Change. London: Verso. 
Declaration on the Granting of Independence to Colonial Countries and Peoples, 14 December 1960. United Nations General Assembly Resolution A/RES/1514 (XV).

Delgado, E., 2019. Trump administration still separating families at border, advocates say. The Guardian [online], 12 February. Available from:

https://www.theguardian.com/us-news/2019/feb/12/trump-el-paso-familyseparations-migrants-immigration [Accessed 8 June 2020].

Du Bois, W.E.B., 2007. To the Nations of the World [online]. Contributed by Blackpast. 29 January. Available from: https://www.blackpast.org/african-americanhistory/1900-w-e-b-du-bois-nations-world/ [Accessed 15 May 2019] (Originally published in 1900).

Faber, D., 2018. Global Capitalism, Reactionary Neoliberalism, and the Deepening of Environmental Injustices. Capitalism, Nature, Socialism [online], 29(2), 8-28. Available from: https://doi.org/10.1080/10455752.2018.1464250 [Accessed 8 June 2020].

Felli, R., 2013. Managing Climate Insecurity by Ensuring Continuous Capital Accumulation: "Climate Refugees" and "Climate Migrants". New Political Economy [online], 18(3), 337-363. Available from: https://doi.org/10.1080/13563467.2012.687716 [Accessed 8 June 2020].

Fraser, N., 2016. Expropriation and Exploitation in Racialized Capitalism: A Reply to Michael Dawson. Critical History Studies [online], 3(1), 163-178. Available from: https://doi.org/10.1086/685814 [Accessed 8 June 2020].

Fricker, M., 2007. Epistemic Injustice: Power and the Ethics of Knowing. Oxford University Press.

Galeano, E., 1997. Open Veins of Latin America: Five Centuries of the Pillage of a Continent. New York: Monthly Review Press.

Gerrard, M.B., 2015. America is the Worst Polluter in the History of the World. We Should Let Climate Change Refugees Settle Here. Washington Post, 25 June.

Gilmore, R.W., 2007. Golden Gulag: Prisons, Surplus, Crisis, and Opposition in Globalizing California. Berkeley/Los Angeles: University of California Press.

Gleick, P.H., 2014. Water, Drought, Climate Change and Conflict in Syria. Weather, Climate, and Society [online], 6, 331-340. Available from: https://doi.org/10.1175/WCAS-D-13-00059.1 [Accessed 8 June 2020].

Glennon, R., 2017. The Unfolding Tragedy of Climate Change in Bangladesh. Scientific American [online], 21 April. Blog post. Available from:

https://blogs.scientificamerican.com/guest-blog/the-unfolding-tragedy-of-climatechange-in-bangladesh [Accessed 15 May 2019].

Gonzalez, C.G., 2011. An Environmental Justice Critique of Comparative Advantage: Indigenous Peoples, Trade Policy, and the Mexican Neoliberal Economic Reforms. University of Pennsylvania Journal of International Law [online], 32(3), 723803. https://scholarship.law.upenn.edu/jil/vol32/iss3/1/ [Accessed 8 June 2020]. 
Gonzalez, C.G., 2013. Environmental Justice and International Environmental Law. In: S. Alam et al., eds. Routledge Handbook of International Environmental Law. New York: Routledge, 77-97.

Gonzalez, C.G., 2015. Environmental Justice, Human Rights, and the Global South. Santa Clara Journal of International Law [online], 13, 151-195. Available from: https://digitalcommons.law.seattleu.edu/faculty/631 [Accessed 8 June 2020].

Gonzalez, C.G., 2016. The Environmental Justice Implications of Biofuels. UCLA Journal of International Law and Foreign Affairs [online], 20, 229-274. Available from: https://digitalcommons.law.seattleu.edu/faculty/771 [Accessed 8 June 2020].

Gonzalez, J., 2011. Harvest of Empire. New York: Penguin Books.

Govind, P.J., and Verchick, R.R.M., 2015. Natural Disaster and Climate Change. In: S. Alam et al., eds. International Environmental Law and the Global South. New York: Cambridge University Press, 491-507. Available from: https://doi.org/10.1017/CBO9781107295414.024 [Accessed 8 June 2020].

Grosfoguel, R., 2006. World-Systems Analysis in the Context of Transmodernity, Border Thinking, and Global Coloniality. Review (Fernand Braudel Center) [online], 29(2), 167-187. Available from: https://www.jstor.org/stable/40241659?seq=1 [Accessed 8 June 2020].

Grosfoguel, R., 2016. What is Racism? Journal of World-Systems Research [online], 22(1), 9-15. Available from: https://doi.org/10.5195/jwsr.2016.609 [Accessed 8 June 2020].

Grosfoguel, R., Oso, L., and Christou, A., 2014. "Racism”, intersectionality and migration studies: framing some theoretical reflections. Identities: Global Studies in Culture and Power [online], 22(6) 635-652. Available from:

https://doi.org/10.1080/1070289X.2014.950974 [Accessed 8 June 2020].

Gutiérrez Rodríguez, E., 2018. The Coloniality of Migration and the "Refugee Crisis": On the Asylum-Migration Nexus, the Transatlantic White European Settler Colonialism-Migration and Racial Capitalism. Refuge [online], 34(1), 16-28. Available from: https://doi.org/10.7202/1050851ar [Accessed 8 June 2020].

Haas Institute for a Fair and Inclusive Society, 2017. Moving Targets: An Analysis of Global Forced Migration [online]. Research report. Available from: http://haasinstitute.berkeley.edu/sites/default/files/haasinstitute moving targets globalmigrationreport publish_web.pdf [Accessed 15 May 2019].

Haraway, D., 2016. Staying with the Trouble: Making Kin in the Chthulucene. Durham: Duke University Press.

Hardin, G., 2015. Lifeboat Ethics: The Case Against Helping the Poor [online]. The Garrett Hardin society. Available from: https://www.garretthardinsociety.org/articles/art lifeboat ethics case against he lping_poor.html [Accessed 15 May 2019] (Originally published in Psychology Today, September 1974).

Hartmann, B., 2010. Rethinking Climate Refugees and Climate Conflict: Rhetoric, Reality and the Politics of Policy Discourse. Journal of International Development 
[online], 22(2), 233-246. Available from: https://doi.org/10.1002/jid.1676 [Accessed 8 June 2020].

Heyward, C., and Ödalen, J., 2016. A Free Movement Passport for the Territorially Dispossessed. In: C. Heyward and D. Roser, eds., Climate Justice in a Non-Ideal World. Oxford University Press, 208-228.

Hochschild, A.R., 2016. Strangers in Their Own Land: Anger and Mourning on the American Right, New York: The New Press.

Hossay, P., 2006. Unsustainable: A Primer for Global Environmental and Social Justice. London: Zed Books.

Ignatiev, N., 1995. How the Irish Became White. New York: Routledge.

Intergovernmental Panel on Climate Change (IPCC), 2014. Climate Change 2014

Synthesis Report [online]. Available from: https://ar5-

syr.ipcc.ch/ipcc/ipcc/resources/pdf/IPCC SynthesisReport.pdf [Accessed 15 May 2019].

Intergovernmental Panel on Climate Change (IPCC), 2018. Global Warming of $1.5^{\circ} \mathrm{C}$ : Summary for Policymakers [online]. Available from: https://www.ipcc.ch/site/assets/uploads/sites/2/2018/07/SR15 SPM version stand alone LR.pdf [Accessed 15 May 2019].

Intergovernmental Panel on Climate Change (IPCC), 2019. Special Report on the Ocean and Cryosphere in a Changing Climate: Summary for Policymakers [online]. Available from: https://www.ipcc.ch/srocc/chapter/summary-for-policymakers/ [Accessed 10 December 2019].

International Covenant on Civil and Political Rights, 16 December 1966 (999 UNTS 171, art. 1). Entered into force 23 March 1976.

International Covenant on Economic Social and Cultural Rights, 16 December 1966 (993 UNTS 3, Art 1). Entered into force 3 January 1976.

International Organization for Migration (IOM), 2014. IOM Outlook on Migration, Environment and Climate Change [online]. Geneva: IOM. Available from: https://publications.iom.int/system/files/pdf/mecc outlook.pdf [Accessed 10 December 2019].

International Organization for Migration (IOM), 2020. Migrant deaths and disappearances [online]. Last updated 17 March. Available from:

https://migrationdataportal.org/themes/migrant-deaths-and-disappearances [Accessed 8 June 2020].

Jakobsson, E., 2018. Norm Formalization in International Policy Formulation: A Framework for Analysis. In: S. Behrman and A. Kent, eds., Climate Refugees: Beyond the Legal Impasse? New York: Routledge, 52-70.

Jewett, C., and Luthra, S., 2018. Immigrant Toddlers Ordered to Appear in Court Alone. Texas Tribune [online], 27 June. Available from: https://www.texastribune.org/2018/06/27/immigrant-toddlers-ordered-appearcourt-alone/ [Accessed 15 May 2019]. 
Kamal, B., 2017. Climate Migrants Might Reach One Billion by 2050. IPS News [online], 21 August. Available from: http://www.ipsnews.net/2017/08/climate-migrantsmight-reach-one-billion-by-2050/ [Accessed 15 May 2019].

Karlin, M., 2018. Climate Refugees Face Militarized Borders. Alternet [online]. Available from: https://www.alternet.org/environment/climate-change-refugeesface-militarized-borders [Accessed 15 May 2019].

Kelman, I., 2018. Islandness within climate change narratives of small island developing states (SIDS). Island Studies Journal [online], 13(1), 149-166. Available from: https://doi.org/10.24043/isj.52 [Accessed 8 June 2020].

King, M.L., 1963. Letter from Birmingham Jail [online]. Available from: https://swap.stanford.edu/20141218230016/http://mlkkpp01.stanford.edu/kingweb/popular requests/frequentdocs/birmingham.pdf [Accessed 15 May 2019].

Klare, M.T., 2004. Blood and Oil: The Dangers and Consequences of America's Growing Dependence on Imported Petroleum. New York: Henry Holt and Company.

Klein, N., 2014. This Changes Everything: Capitalism vs the Climate. New York: Simon \& Schuster.

Klein, N., 2016. Let Them Drown: The Violence of Othering in a Warming World. London Review of Books [online], 38(11), 1-12. Available from: https://www.lrb.co.uk/the-paper/v38/n11/naomi-klein/let-them-drown [Accessed 8 June 2020].

Klepp, S., 2017. Climate Change and Migration. Oxford Research Encyclopedia of Climate Change [online]. April. Available from: https://doi.org/10.1093/acrefore/9780190228620.013.42 [Accessed 15 May 2019].

Klepp, S., and Herbeck, J., 2016. The politics of environmental migration and climate justice in the Pacific region. Journal of Human Rights and the Environment [online], 7(1), 54-73. Available from: https://doi.org/10.4337/jhre.2016.01.03 [Accessed 8 June 2020].

Kotef, H., 2015. Movement and the Ordering of Freedom: On Liberal Governance of Mobility. Durham: Duke University Press.

Kronk Warner, E.A., 2015. South of South: Examining the International Climate Regime from an Indigenous Perspective. In: S. Alam et al., eds. International Environmental Law and the Global South. New York: Cambridge University Press, 451-468.

Kuehn, R., 2000. A Taxonomy of Environmental Justice. Environmental Law Reporter [online], vol. 30, 10681-10703. Available from: https://ir.lib.uwo.ca/cgi/viewcontent.cgi?article=1137\&context=aprci [Accessed 8 June 2020].

Lewis, S., and Maslin, M., 2015. Defining the Anthropocene. Nature [online], 519, 171180. Available from: https://doi.org/10.1038/nature14258 [Accessed 8 June 2020].

Lewis, S., and Maslin, M., 2018. The Human Planet. London: Penguin Books. 
Lindgren, T., 2018. Ecocide, genocide and the disregard of alternative life-systems. The International Journal of Human Rights [online], 22(4), 525-549.

https://doi.org/10.1080/13642987.2017.1397631 [Accessed 8 June 2020].

Liptak, A. and Shear, M.D., 2018. Trump's Travel Ban is Upheld By Supreme Court. New York Times [online], 26 June. Available from:

https://www.nytimes.com/2018/06/26/us/politics/supreme-court-trump-travelban.html [Accessed 8 June 2020].

Lowenstein, A., 2015. Disaster Capitalism: Making a Killing Out of Catastrophe. New York/London: Verso.

Maguire, A., and McGee, J., 2017. A Universal Human Right to Shape Responses to a Global Problem? The Role of Self-Determination in Guiding the International Legal Response to Climate Change. Review of European Community and International Environmental Law [online], 26(1), 54-68. Available from: https://doi.org/10.1111/reel.12193 [Accessed 8 June 2020].

Marks, S., 2011. Human Rights and Root Causes. Modern Law Review [online], 74(1), 5778. Available from: https://doi.org/10.1111/j.1468-2230.2010.00836.x [Accessed 8 June 2020].

Massey, D.S., 2000. The Social and Economic Origins of Immigration. Annals of the American Academy of Political and Social Sciences [online], 510(1), 60-72. Available from: https://doi.org/10.1177/0002716290510001005 [Accessed 8 June 2020].

Mbembe, A., 2016. The Society of Enmity. Radical Philosophy [online], 200 (Nov/Dec), 114. Available from: https://www.radicalphilosophyarchive.com/issuefiles/rp200 article mbembe society of enmity.pdf [Accessed 15 May 2019].

McAdam, J., 2012. Climate Change, Forced Migration, and International Law. Oxford University Press.

McAdam, J., 2016. From the Nansen Initiative to the Platform on Disaster Displacement: Shaping International Approaches to Climate Change, Disasters and Displacement. University of New South Wales Law Journal [online], 39(4), 15181546. Available from: https://doi.org/10.2139/ssrn.2901910 [Accessed 8 June 2020].

Methmann, C., and Oels, A., 2015. From “Fearing" to "Empowering" Climate Refugees: Governing Climate-Induced Migration in the Name of Resilience. Security Dialogue [online], 46(1), 51-68. Available from: https://doi.org/10.1177/0967010614552548 [Accessed 8 June 2020].

Metzl, J.M., 2019. Dying of Whiteness: How the Politics of Racial Resentment is Killing America's Heartland. New York: Basic Books.

Mickelson, K., 2005. Leading Towards a Level Playing Field, Repaying Ecological Debt, or Making Environmental Space: Three Stories about International Environmental Cooperation. Osgoode Hall Law Journal [online], 43(1/2), 137-170. Available from: http://digitalcommons.osgoode.yorku.ca/ohlj/vol43/iss1/6 [Accessed 8 June 2020].

Miller, T., 2017. The United States is Polluting the World and Locking Refugees Out. The Nation [online], 7 December. Available from: 
https://www.thenation.com/article/the-united-states-is-polluting-the-world-andlocking-refugees-out/ [Accessed 15 May 2019].

Moore, J.W., 2015. Capitalism in the Web of Life. New York: Verso.

Moore, J.W., ed., 2016. Anthropocene or Capitalocene? Nature, History, and the Crisis of Capitalism. Oakland: PM Press.

Nansen Initiative, 2015. Agenda for the Protection of Cross-Border Displaced Persons in the Context of Disasters and Climate Change [online]. Agenda for the Protection of Cross-Border Displaced Persons in the Context of Disasters and Climate Change (volume I). December. Available from: https://nanseninitiative.org/wpcontent/uploads/2015/02/PROTECTION-AGENDA-VOLUME-1.pdf [Accessed 15 May 2019].

Natarajan, U., 2012. TWAIL and the Environment: The State of Nature, the Nature of the State, and the Arab Spring. Oregon Review of International Law [online], 14(1), 177-202. Available from: http://hdl.handle.net/1794/12605 [Accessed 8 June 2020].

Nawyn, S.J., 2019. Refugees in the United States and the Politics of Crisis. In: C. Menjívar, M. Ruiz and I. Ness, eds., The Oxford Handbook of Migration Crises. Oxford University Press.

Nixon, R., 2013. Slow Violence and the Environmentalism of the Poor. Cambridge, MA: Harvard University Press.

Olivares, M., 2016. Intersectionality and the Intersection of Profiteering and Immigration Detention. Nebraska Law Review [online], 94(4), 963-1027. Available from: https://digitalcommons.unl.edu/nlr/vol94/iss4/5 [Accessed 8 June 2020].

Paris Agreement to the United Nations Framework Convention on Climate Change, 12 December 2015 (1771 U.N.T.S. 107).

Pascoe, S., 2015. Sailing the Waves on Our Own: Climate Migration, Self-

Determination, and the Carteret Islands. Queensland University of Technology Law Review [online], 15(2), 72-85. Available from:

https://doi.org/10.5204/qutlr.v15i2.610 [Accessed 8 June 2020].

Peet, R., 2009. Unholy Trinity: The IMF, World Bank and WTO. $2^{\text {nd }}$ ed. London: Zed Books.

People's Agreement, 2010. World People's Conference on Climate Change and the Rights of Mother Earth [online]. Cochabamba, Bolivia. Available from: https://pwccc.wordpress.com/support/ [Accessed 15 May 2019].

Pérez, B.F., 2018. Beyond the Shortcomings of International Law: A Proposal for the Legal Protection of Climate Migrants. In: S. Behrman and A. Kent, eds., Climate Refugees: Beyond the Legal Impasse? New York: Routledge, 214-230.

Platform on Disaster Displacement, 2018. State-led, Regional, Consultative Processes: Opportunities to Develop Legal Frameworks on Disaster Displacement. In: S. Behrman and A. Kent, eds., Climate Refugees: Beyond the Legal Impasse? New York: Routledge, 126-154. 
Pulido, L., 2018. Racism and the Anthropocene. In: G. Mitman, M. Amiero and R. Emmett, eds., Future Remains: A Cabinet of Curiosities. University of Chicago Press, 116-128.

Quijano, A., 2000. Coloniality of Power, Eurocentrism, and Latin America. Nepantla: Views from the South, 1(3), 533-580.

Quijano, A., 2007. Coloniality and Modernity/Rationality. Cultural Studies [online], 21(2), 168-178. Available from: https://doi.org/10.1080/09502380601164353 [Accessed 8 June 2020].

Quijano, A., 2014. Cuestiones y horizontes: de la dependencia histórico-estructural a la colonialidad/descolonialidad del poder. Buenos Aires: CLACSO.

Raftery, A.E., et al., 2017. Less than $2^{\circ} \mathrm{C}$ Warming by 2100 Unlikely. Nature Climate Change [online], 7, 637-641. Available from: https://doi.org/10.1038/nclimate3352 [Accessed 8 June 2020].

Rajagopal, B., 2003. International Law from Below: Development, Social Movements and Third World Resistance. Cambridge University Press.

Ransan-Cooper, H., et al., 2015. Being(s) Framed: The Means and Ends of Framing Environmental Migrants. Global Environmental Change [online], 35, 106-115. Available from: https://doi.org/10.1016/j.gloenvcha.2015.07.013 [Accessed 8 June 2020].

Reed, A., 2013. Marx, Race and Neoliberalism. New Labor Forum [online], 22(1), 49-57. Available from: https://doi.org/10.1177/1095796012471637 [Accessed 8 June 2020].

Richards, S., and Peña, D.C., 2017. An Environmental Justice Critique of Carceral Antiecology. In: A.J. Nocella II, K.A. Ducre and J. Lupinacci, eds., Addressing Environmental and Food Justice toward Dismantling the School-to-Prison Pipeline: Poisoning and Imprisoning Youth. New York: Palgrave Macmillan, 115-136.

Roberts, J.T., and Parks, B.C., 2008. A Climate of Injustice: Global Inequality, North-South Politics, and Climate Policy. Cambridge, MA: MIT Press.

Robinson, C., 2000. Black Marxism: The Making of the Black Radical Tradition. Chapel Hill: University of North Carolina Press.

Rodney, W., 1972. How Europe Underdeveloped Africa. London: Bogle-L'Ouverture Press.

Rogelj. J., et al., 2016. Paris Agreement Climate Proposals Need a Boost to Keep Warming Well Below $2^{\circ} \mathrm{C}$. Nature [online], 534, 631-639. Available from: https://doi.org/10.1038/nature18307 [Accessed 8 June 2020].

Ross, N., 2017. Climate migrants will need more than "dignity". Ideasroom [online], 20 November. Available from:

https://www.newsroom.co.nz/@ideasroom/2017/11/20/61589/climate-migrantswill-need-more-than-dignity\# [Accessed 15 May 2019].

Saad, A., 2017. Toward a Justice Framework for Understanding and Responding to Climate Migration and Displacement. Environmental Justice [online], 10(4), 98-101. Available from: https://doi.org/10.1089/env.2016.0033 [Accessed 8 June 2020]. 
Saito, N.T., 2014. Tales of Color and Colonialism: Racial Realism and Settler-Colonial Theory. Florida A\&M University Law Review [online], 10(1), 1-108. Available from: http://commons.law.famu.edu/famulawreview/vol10/iss1/3 [Accessed 8 June 2020].

Santos, B.S., 2014. Epistemologies of the South: Justice Against Epistemicide. New York: Paradigm.

Santos, B.S., 2018. The End of the Cognitive Empire: The Coming of Age of Epistemologies of the South. Durham/London: Duke University Press.

Sassen, S., 2014. Expulsions: Brutality and Complexity in the Global Economy. Cambridge, MA: Harvard University Press.

Schlosberg, D., and Collins, L., 2014. From environmental to climate justice: climate change and the discourse of environmental justice. WIREs Climate Change [online], 5(3), 359-374. Available from: https://doi.org/10.1002/wcc.275 [Accessed 8 June 2020].

Scott, D.N., and Smith, A.A., 2017. The abstract subject of the climate migrant displaced by the rising tides of the green energy economy. Journal of Human Rights and the Environment [online], 8, 30-50. Available from: https://doi.org/10.4337/jhre.2017.01.02 [Accessed 8 June 2020].

Sendai Framework for Disaster Risk Reduction, 2015 [online]. Sendai: Third United Nations World Conference on Disaster Risk Reduction, 14-18 March. Available from: https://www.preventionweb.net/files/43291_sendaiframeworkfordrren.pdf [Accessed 15 May 2019].

Sheller, M., 2018. Mobility Justice: The Politics of Movement in an Age of Extremes. London: Verso.

Simms, A., 2009. Ecological Debt: Global Warming and the Wealth of Nations. $2^{\text {nd }}$ ed. University of Chicago Press.

Sorensen, S., et al., 2018. Climate change and women's health: Impacts and policy directions. PLoS Medicine [online], 15(7), 1-10. Available from: https://doi.org/10.1371/journal.pmed.1002603 [Accessed 15 May 2019].

Soyapi, C., and Kotzé, L.J., 2016. Environmental Racism, Slow Violence and the Extractive Industry in Post-apartheid South Africa: Marikana in Context. Verfassung und Recht in Übersee [online], 49, 393-415. Available from: https://doi.org/10.5771/0506-7286-2016-4-393 [Accessed 8 June 2020].

Steffen, W., et al., 2015. Planetary boundaries: Guiding human development on a changing planet. Science [online], 347(6223). Available from: https://doi.org/10.1126/science.1259855 [Accessed 8 June 2020].

Sundberg, J., 2008. Placing Race in Environmental Justice Research in Latin America. Society and Natural Resources [online], 21(7), 569-582. Available from: https://doi.org/10.1080/08941920802111538 [Accessed 8 June 2020].

Telford, A., 2018. A threat to climate-secure European futures? Exploring racial logics and climate-induced migration in US and EU climate security discourses. 
Geoforum [online], 96, 268-277. Available from:

https://doi.org/10.1016/j.geoforum.2018.08.021 [Accessed 8 June 2020].

Temper, L., del Bene, D., and Martinez-Alier, J., 2015. Mapping the Frontiers and Front Lines of Global Environmental Justice: The EJAtlas. Journal of Political Ecology [online], 22(1), 255-278. Available from: https://doi.org/10.2458/v22i1.21108 [Accessed 8 June 2020].

The Week, 2018. Europe's Hostile Environment Deters Asylum Seekers. The Week [online], 19 June. Available from: http://www.theweek.co.uk/94383/is-europe-shostile-environment-turning-off-asylum-seekers. [Accessed 15 May 2019].

Tichenor, D.J., 2002. Dividing Lines: The Politics of Immigration Control in America. Princeton University Press.

Tsosie, R., 2007. Indigenous Peoples and Environmental Justice: The Impact of Climate Change. University of Colorado Law Review [online], 78, 1625-1677. Available from: https://papers.ssrn.com/sol3/papers.cfm?abstract id=1399659 [Accessed 8 June 2020].

Tsosie, R., 2012. Indigenous Peoples and Epistemic Injustice: Science, Ethics and Human Rights. Washington Law Review [online], 87(4), 1133-1200. Available from: https://digitalcommons.law.uw.edu/wlr/vol87/iss4/5

United Nations Environment Programme (UNEP), 2018. The Emissions Gap Report 2018. Nairobi: UNEP.

United Nations Environment Programme (UNEP), 2019. The Emissions Gap Report 2019. Nairobi: UNEP.

United Nations Framework Convention on Climate Change (UNFCCC), 1992 (1771 UNTS 109). Concluded at Rio de Janeiro, 2 May 1992. Entered into force 21 March 1994.

United Nations Framework Convention on Climate Change (UNFCCC), 29 January 2016. Report of the Conference of the Parties on its Twenty-First Session (U.N. Doc. FCCC/CP/2015/10/Add.1).

United Nations Framework Convention on Climate Change (UNFCCC), 31 January 2014. Report of the Conference of the Parties on Its Nineteenth Session (U.N. Doc. FCCC/CP/2013/10/Add.1).

United Nations Framework Convention on Climate Change, Adoption of the Paris Agreement, 26 January 2016. (Decision 1/CP.21, 49, FCCC/CP/2015/10/Add.1).

United Nations High Commissioner for Human Rights (UNHCHR), 2009. Report of the Office of the United Nations High Commissioner for Human Rights on the relationship between climate change and human rights (U.N. Doc. A/HRC/10/61).

United Nations High Commissioner for Human Rights (UNHCHR), 2019. Status of Ratification Interactive Dashboard, Convention for the Protection of the Rights of All Migrant Workers and Members of their Families [online]. Available from: http://indicators.ohchr.org/ [Accessed 15 May 2019]. 
United Nations High Commissioner for Refugees (UNHCR), 2018. Global Trends: Forced Displacement in 2017 [online]. Available from: http://www.unhcr.org/5b27be547.pdf [Accessed 15 May 2019].

United Nations Human Rights Committee, 7 January 2020. Views adopted by the Committee under article 5(4) of the Optional Protocol, concerning communication No. 2728/2016, CCPR/C/127/D/2728/2016.

United Nations Human Rights Council, 2018. Report of the Special Rapporteur on the Situation of Human Rights Defenders (U.N. Doc. A/HRC/37/51).

United Nations Human Rights Council, 2019. Climate Change and Poverty, Report of the Special Rapporteur on Extreme Poverty and Human Rights (A/HRC/41/39), 25 June.

van der Vliet, J., 2018."'Climate Refugees": A Legal Mapping Exercise. In: S. Behrman and A. Kent, eds., Climate Refugees: Beyond the Legal Impasse? New York: Routledge, 16-33.

Verchick, R.R.M., 2018. Can “Loss and Damage" Carry the Load? Philosophical Transactions of the Royal Society of London [online], 376, 20170070. Available from: https://doi.org/10.1098/rsta.2017.0070 [Accessed 8 June 2020].

Walia, H., 2013. Undoing Border Imperialism. Chico: AK Press.

Walicki, N., and Swain, M., 2016. Pushed Aside: Displaced for "Development" [online]. Thematic report. India Internal Displacement Center/Norwegian Refugee Council. July. Available from: http://www.internaldisplacement.org/sites/default/files/publications/documents/201607-ap-indiapushed-aside-en.pdf [Accessed 15 May 2019].

Walshe, R.A., and Stancioff, C.E., 2018. Small island perspectives on climate change. Island Studies Journal [online], 13(1), 13-24. Available from: https://doi.org/10.24043/isj.56 [Accessed 8 June 2020].

Warner, K., 2011. Global Environmental Change and Migration: Methodological Considerations from Ground-breaking Global Survey. Population and Environment [online], 33(1), 3-27. Available from: https://www.jstor.org/stable/41487561 [Accessed 8 June 2020].

Warner, K., 2012. Human migration and displacement in the context of adaptation to climate change: the Cancun Adaptation Framework and potential for future action. Environment and Planning C: Government and Policy [online], 30(6), 10611077. Available from: https://doi.org/10.1068/c1209j [Accessed 8 June 2020].

Warner, K., et al., 2009. In Search of Shelter: Mapping the Effects Of Climate Change On Human Migration and Displacement [online]. Report written for UN University, CARE International, Columbia University, the UN Refugee Agency and World Bank. Available from: https://www.ciesin.columbia.edu/documents/clim-migrreport-june09 final.pdf [Accessed 15 May 2019].

Willcox, S., 2016. Climate Change Inundation, Self-Determination, and Atoll Islands. Human Rights Quarterly [online], 38(4), 1022-1037. Available from: https://doi.org/10.1353/hrq.2016.0055 [Accessed 8 June 2020]. 
Williams, E., 1994. Capitalism and Slavery. Chapel Hill: University of North Carolina Press.

Williams, R.A., 1991. Columbus' Legacy: Law as an Instrument of Racial Discrimination against Indigenous Peoples' Rights of Self-Determination. Arizona Journal of International and Comparative Law, 8, 51-75.

Wolfe, P., 2016. Traces of History: Elementary Structures of Race. London/New York: Verso.

Wood, S., 2018. The Intersection of Human Trafficking and Immigration. Bill of Health [online], 27 June. Available from:

http://blog.petrieflom.law.harvard.edu/2018/06/27/the-intersection-of-humantrafficking-and-immigration/ [Accessed 15 June 2019].

Wyman, K.M., 2017. Limiting the National Right to Exclude. University of Miami Law Review, 72(2), 425-475. Available from:

https://repository.law.miami.edu/umlr/vol72/iss2/6/ [Accessed 8 June 2020].

Yusoff, K., 2018. A Billion Black Anthropocenes or None. Minneapolis: University of Minnesota Press.

Zárate-Toledo, E., Patiño, R., and Fraga, J., 2019. Justice, social exclusion and indigenous opposition: A case study of wind energy development on the Isthmus of Tehuantepec, Mexico. Energy Research \& Social Science [online], 54, 1-11. Available from: https://doi.org/10.1016/j.erss.2019.03.004 [Accessed 8 June 2020]. 